This manuscript has been submitted for publication in Earth Surface Processes and Landforms. This preprint has not undergone peer-review and subsequent versions of the manuscript may differ from this version. If accepted, the final version will be available via a DOI link on this page. Please contact the corresponding author by email with any queries - mstyllas@gmail.com Prepared for EarthArxiv on October 19th 2021. 


\section{The relative contributions of weathering and aeolian inputs to postglacial formation of Mediterranean alpine loess}

MICHAEL STYLLAS ${ }^{1,2}$, CHRISTOS PENNOS ${ }^{3,5}$, MATHIEU GHILARDI ${ }^{4}$, AUREL PERSOIU ${ }^{5,6}$, LAMBRINI PAPADOPOULOU ${ }^{7}$, NIKOLAOS KANTIRANIS ${ }^{7}$, ELINA AIDONA $^{8}$,

${ }^{1}$ Geoservice Ltd., Eirinis 14 Street, 55236, Thessaloniki, Greece (Email: mstyllas@gmail.com)

${ }^{2}$ Ecole Polytechnique Federal de Lausanne - EPFL, Lausanne, CH-1015, Switzerland

${ }^{3}$ Department of Geography, University of Bergen, Fosswinckels Gate 6, 5007, Bergen, Norway

${ }^{4}$ CEREGE - UMR 7330 CNRS Europôle de l'Arbois BP80 13545 Aix-en-Provence CEDEX 04 - France

${ }^{5}$ Emil Racoviţă Institute of Speleology, Romanian Academy, Cluj-Napoca, 400006, Romania

${ }^{6}$ Romanian Institute of Science and Technology, Cluj-Napoca, 400022, Romania

${ }^{7}$ Department of Mineralogy, Petrology and Economic Geology, School of Geology, Aristotle University of Thessaloniki, Thessaloniki, 541 24, Greece

${ }^{8}$ Department of Geophysics, School of Geology, Aristotle University of Thessaloniki, Thessaloniki, 541

24, Greece 
2 Between the southern margin of the European loess belt and Sahara Desert, thin and irregularly

3 distributed loess deposits occur in Mediterranean mountains. During the most recent deglaciation, along 4 the Pleistocene-Holocene boundary, the deposition of glacial, periglacial and outwash sediments, was 5 the main local source of Mediterranean alpine loess, whereas proximal alluvial planes comprised a secondary source. The mid-Holocene termination of African Humid Period and subsequent aridification of Sahara Desert occurred simultaneously with a change of the regional climate from Atlantic to

8 Mediterranean-dominated, characterized by frequent episodes of southerly winds. This resulted to a 9 change of the loess source, as deflation of quartz rich silts enriched in $\mathrm{Zr}$ during intense episodes of Sahara dust transport became more dominant. Here, a $32 \mathrm{~cm}$ loess profile from the Plateau of Muses (PM), below the summit of Mount Olympus, Greece, is investigated on the basis of grain size, mineralogy, environmental magnetism and geochemistry. Comparisons of loess samples with glacial and periglacial deposits, enables us to differentiate relative contributions of local sources and allochthonous aeolian inputs. Calcite sand rich in feldspars makes up the glacial and periglacial clast free matrix. In contrast, PM loess is composed by clay and fine silt fractions with minor calcite sand contributions. The mineralogical matrix of loess contains quartz, phyllosilicates and mixed layer clays, while its geochemical composition contains high amounts of detrital Fe-Ti oxides and aeolian transported $\mathrm{Al}$ and $\mathrm{Zr}$. Based on the multi-proxy approach applied here, the loess profile is partitioned in three layers. Holocene average deposition rates $(\sim 2.5 \mathrm{~cm} / \mathrm{ka})$ broadly agree with modern Sahara dust deposition $(\sim 2.0 \mathrm{~cm} / \mathrm{ka})$ and long-term postglacial Mediterranean mountain denudation rates $(\sim 0.5$ $\mathrm{cm} / \mathrm{ka}$ ). Such low rates provided ample time for post depositional modifications, such as decalcification, deferrification and removal of $\mathrm{K}$, evident from the trends of chemical weathering proxies $\mathrm{Ca} / \mathrm{Sr}, \mathrm{Fe} / \mathrm{Ti}$ and $\mathrm{K} / \mathrm{Rb}$, respectively. 
28 Keywords Loess, alpine plateau, glacial debris, Sahara dust, pedogenesis, chemical weathering, Mount

29 Olympus, Greece. 
The most recent deglaciation of the Mediterranean mountains between 12 and $9.5 \mathrm{ka} \mathrm{BP}$ resulted to deposition of large sequences of glacial, periglacial and outwash sediments that were mainly confined in the highest valleys of the massifs (Hughes and Woodward, 2016; Oliva et al., 2018; Allard et al., 2020). Antecedent to glacial retreat was the deposition of loess and subsequent formation of alpine soils on moraines, plateaus and outwash plains (e.g. Muhs 2007). Synergistic to the in-situ genesis of alpine soils, is the deposition windblown dust, which results to the formation of alpine loess soils (Muhs and Benedict, 2006; Küfmann, 2008; Lawrence et al., 2013; Drewnik et al., 2014; Yang et al., 2016; Gild et al., 2018). The multi-proxy analysis of postglacial alpine soils and loess deposits provides insights on the local climate - weathering relations (Egli et al., 2010; Egli 2014; Yang et al., 2016) and further determines the rate of geomorphic processes, such as landscape denudation. Furthermore, the study of deflated sediments within alpine soils and loess can provide insights on the local and regional atmospheric circulation patterns, reflected by the depositional dynamics of aeolian dust (e.g. Muhs et al., 2007).

In the Mediterranean region, the formation of loess is influenced to a large extent by its proximity to Sahara Desert (Pye, 1995; Goudie and Middleton, 2001; Stuut et al., 2009), but also to other local sources of deflated material such as glacial moraines and periglacial slopes, alluvial planes and sand dune fields (Amit et al., 2020; Lehmkuhl et al., 2021). Sahara dust comprises the parent material of red soils, formed on fluvial and coastal terraces (e.g. Durn, 2003), whereas on the Mediterranean mountains, thin drapes of loessic alpine soils form on karstic depressions, glacial moraines, outwash plains and glaciofluvial deposits (e.g. Rellini et al., 2009). Similarly, alpine loess soils with significant Sahara dust subadditions are found past the margin of Mediterranean basin, as for example in Carpathian Basin (Varga et al., 2016) and the Northern Calcareous Alps (Küffman et al., 2008). In these locations, the formation of alpine soil loess sequences consists mainly of windblown silt rich in quartz and heavy minerals of North African crustal origin. In alpine settings with carbonate bedrock lithologies, the aeolian deposition is contemplated by the transport and deposition of carbonate weathering debris and 
carbonate dissolution products, which form an insoluble residue incorporated in the pedogenic sequences (Durn 2003; Varga et al., 2016). Evidence from marine and lacustrine sediment archives from the Mediterranean, show an intensification of Sahara dust transport after the termination of the African Humid Period (AHP) around $\sim 6 \mathrm{ka}$ BP, due to increasing deflation of silt from desiccated areas in northern Africa (e.g. Jimenez-Espejo et al., 2014; Ehrmann et al., 2017). Also, Holocene climatic reconstructions from ice cave deposits in Romania, suggest that the end of the AHP coincided with a shift in the winter climate of southeast Europe from Atlantic to Mediterranean dominated (Persoiu et al., 2017).

This study presents for the first time a precise characterization of Mount Olympus loess, by combing grain size distributions, mineralogical and geochemical compositions, and magnetic properties. An attempt to discern the relative contributions of local erosion, aeolian inputs and post depositional weathering since the onset of the most recent deglaciation $(\sim 12 \mathrm{ka}$ BP) is undertaken through a multiproxy approach. Mount Olympus loess gives a unique opportunity to assess the contributions of local and allochthonous sources and the paleoclimatic reconstruction potential of similar deposits, which are widespread within modern Mediterranean paraglacial environments.

\section{SETTING}

\section{Climate}

Mount Olympus is the highest mountain of Greece, rising 2918 meters above the Aegean Sea (Fig. 1). In the lower part of the mountain, Mediterranean type climate prevails with wet winters and generally dry summers. Wet winters are linked to cyclogenesis in the Aegean Sea basin that results from enhanced mid-latitude westerlies (Fig. 1 pattern B) and the influence of Atlantic climate (Xoplaki et al., 2000). This pattern was dominant during the first part of the Holocene (Peyron et al., 2017). Dry winters are associated with outbreaks of northerly continental cold and dry airflows (Fig. 1 pattern B) funneling through the large fluvial valleys exiting on the Aegean Sea (Rohling et al., 2002), which are connected to the presence of high-pressure systems over the northern Balkans and/or Siberia (e.g. Xoplaki et al., 
2000; Bartzokas et al., 2003). This pattern was persistent throughout the Holocene, when short periods of cold and dry winters linked to the intensification of Siberian High (e.g. Rohling et al., 2002; Marino et al., 2009) and resulted in Mediterranean rainfall minima associated Sahara dust transport episodes (Zielhofer et al., 2017a). The transport of Sahara dust in the North Aegean occurs today under strong southerly (Sirocco) winds (Fig. 1 pattern C) during the winter and spring (Nastos, 2012), but there is lack of evidence of how the southerly winds outbreaks evolved during the Holocene. However, the study of Mediterranean alpine loess archives, where the Sahara dust signal is not blurred by erosion, reworking and pedogenesis, can provide valuable information on the tempo of southerly warm and moist wind outbreaks and their impacts on different ecosystems.

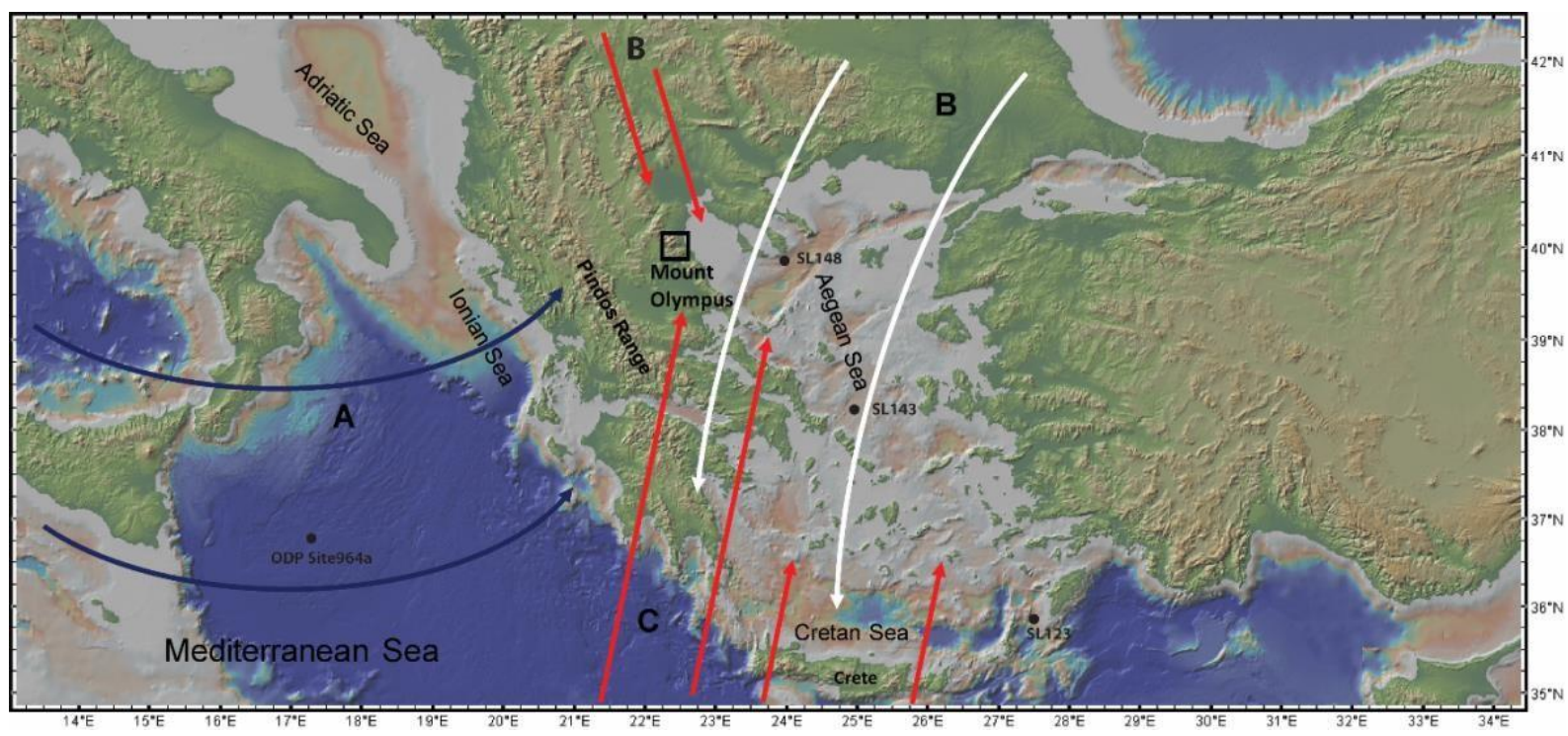

Fig. 1. General setting of Mount Olympus, in relation to the dominant atmospheric patterns. (A) Mid-latitude westerlies causing Mediterranean cyclogenesis and wet winters over the study area. (B) Cold and dry air masses of polar origin, resulting in low winter precipitation. (C) Southerly sirocco winds favoring intense transport Sahara dust and heat convection to the study area. Topographic and bathymetric background provided by Geomapapp (http://www.geomapapp.org).

\section{Glacial erosion}

The geologic structure of Mount Olympus involves a stratigraphic upwards sequence of Triassic, and 
Lower Cretaceous to Eocene metacarbonates, uplifted since the late Miocene along a major NW - SE trending frontal fault (Fig. 2A) (Nance, 2010). During uplift, deposition of erosional products along the eastern (marine) and the western (continental) piedmonts occurred (Fig. 2A). Their Quaternary counterparts include thick sequences of glaciofluvial and alluvial fan deposits with intercalated soils, exposed along the main river valleys and the frontal fault scarp (Fig. 3 in Smith et al., 2006). During the Last Glacial Maximum (LGM), between 28 and 24 ka BP (Allard et al., 2020), an ice cap covered Mount Olympus' highest cirques and upland plateaus extending to elevations of $\sim 2000 \mathrm{~m}$ (Kuhlemann et al., 2008). The post LGM retreat was followed by a Late Glacial (LG) glacier expansion at $\sim 15 \mathrm{ka}$ BP that was confined in the highest cirques at elevations above $2200 \mathrm{~m}$ (Styllas et al., 2018).

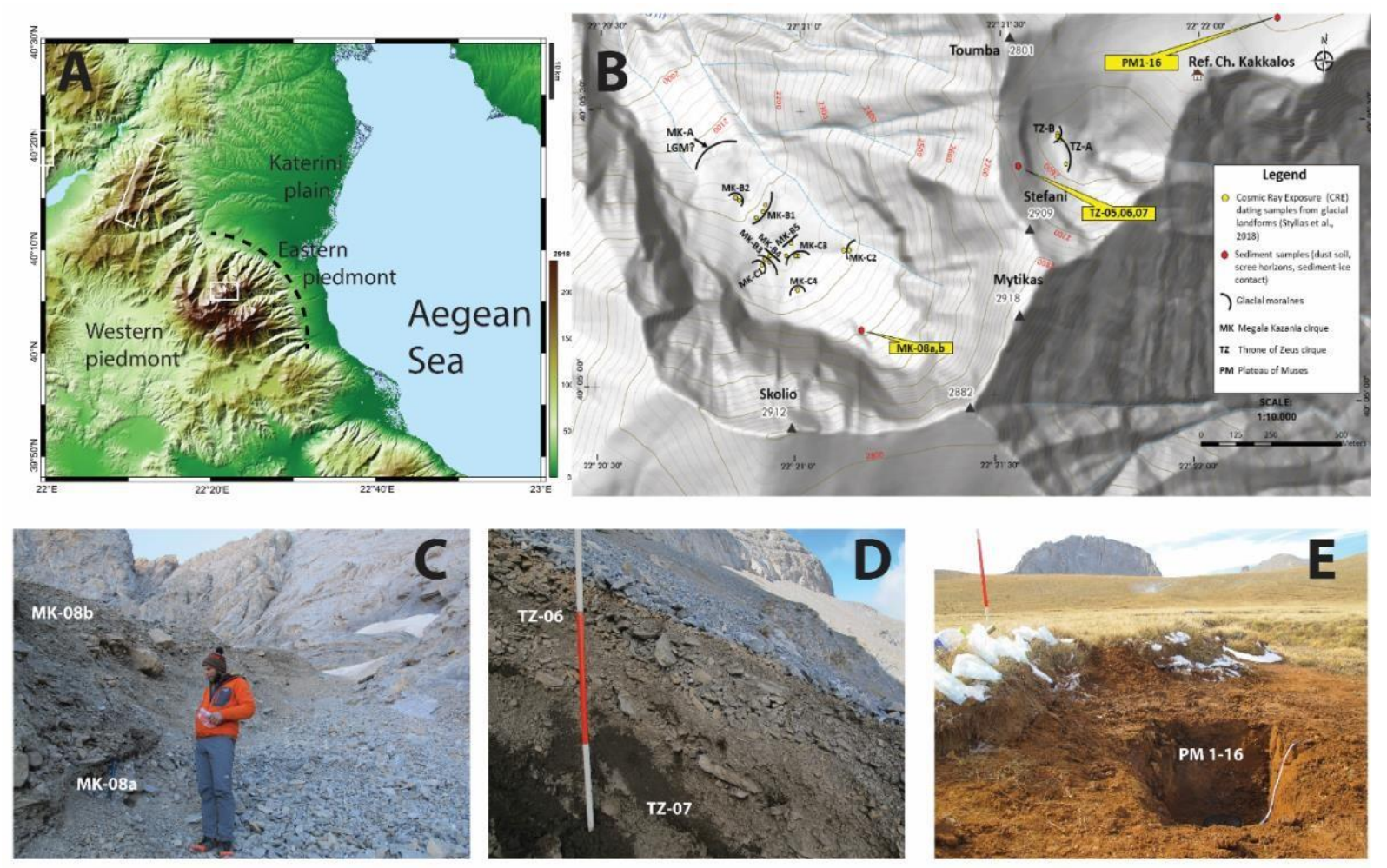

Fig. 2. Geomorphological properties of the study area. A. Setting of Mount Olympus (white box), with the two piedmonts along the marine and continental sides, the main frontal fault (dashed line) the mountaintop of adjacent Pieria Mountains (white box) and Katerini alluvial plane. B. The highest cirques of Mount Olympus with the respective locations of dated moraines (Styllas et al., 2018) and the sampling locations considered in this study (yellow boxes). C. Upper left inset shows and the red box shows the geographical position of the map. (C) Sediment samples from clast free horizons of a lateral moraine in Megala Kazania (MK) cirque. (D) Stratified scree under 
the rock face of Stefani (2909m) in the Throne of Zeus (TZ) cirque. (E) Postglacial / Holocene loess accumulation in the Plateau of Muses (PM).

The most recent moraine stabilization phase common to the highest cirques of Megala Kazania (MK) and Throne of Zeus (TZ) (Fig 2B), occurred at $12 \mathrm{ka} \mathrm{BP}$ and has been tentatively ascribed to Younger Dryas (Styllas et al., 2018), with thick accumulations of sediments below MK and TZ headwalls. These occur either as stratified scree slopes, or as glacial till forming lateral moraines (Fig. 2B \& C). Away from the main depocenters of the most recent glacial activity, periglacial movements, and outwash deposits along with the contribution of aeolian deflation of glacially grinded carbonate sands and silts become dominant.

\section{Sources of aeolian dust}

The study of north Aegean core SL-148 marine sediments, suggests that the major sources of aeolian dust transport in the North Aegean Sea (Fig. 1) is Sahara Desert (Hamann et al., 2008). Direct observations from Mount Olympus over the past 15 years confirm the existence of severe episodes of Sahara dust deposition during the winter and spring, where it forms distinct layers within the snowpack, whereas measurements of Sahara dust deposition rates in Crete (Fig. 1), range between 0.66 and 2.14 $\mathrm{cm} / \mathrm{ka}$ (Niéhlen et al., 1995). Additional dust sources are the eroded mountaintops of the ophiolitic Pieria Mountains and the alluvial plain of Katerini (Fig. 2A). The sediments of Katerini alluvial plains have mainly ophiolitic rock formations, as they drain Pieria Mountains (Krahtopoulou and Veropoulidou, 2017). Transport of deflated material from the alluvial plains can occur during periods of northern wind outbreaks (Fig. 1, pattern B) and by summer convection, triggered by pronounced temperature gradients between the coast and the upper mountain, which can reach $8-10^{\circ} \mathrm{C} / \mathrm{km}$ (Styllas et al., 2016).

\section{Plateau of Muses loess}

The Plateau of Muses (PM) is a planar depositional surface at $2600 \mathrm{~m}$, bounded by the TZ cirque lateral moraine ridge to the south, and by several gentle sloping glacially eroded peaks along its northern, eastern 
and western margins (Fig 2E). The Plateau of Muses extents $0.8 \mathrm{~km}^{2}$ and is covered by unconsolidated glacial and periglacial sediments. Periglacial features such as solifluction beds are present below the exposed bedrock of the surrounding peaks, while patterned grounds exist along its topographically lower surface (Styllas et al., 2018). These features are tentatively considered to have formed during cold intervals over the last $\sim 12 \mathrm{ka} \mathrm{BP}$, following the deglaciation of TZ cirque, but may be still active today as the permafrost elevation of the region is placed at $2700 \mathrm{~m}$ (Dobiński, 2005). The formation of PM is the result of the combined action of glacial scouring and karstic dissolution. The low relief in combination to the elliptical to circular plan shape of the plateau, points to a doline type karstic depression filled with glacial and periglacial sediments with a thickness between 4 to $10 \mathrm{~m}$ (unpublished data from geophysical survey). The surface layer $(>35 \mathrm{~cm}$ ) of PM sedimentary sequence is composed by a red to yellow homogenous finegrained accumulation, with its basal part composed by glacial and/or snowmelt outwash limestone sand and gravel, mixed with silty sediments (Fig. 2E, Fig. 3).

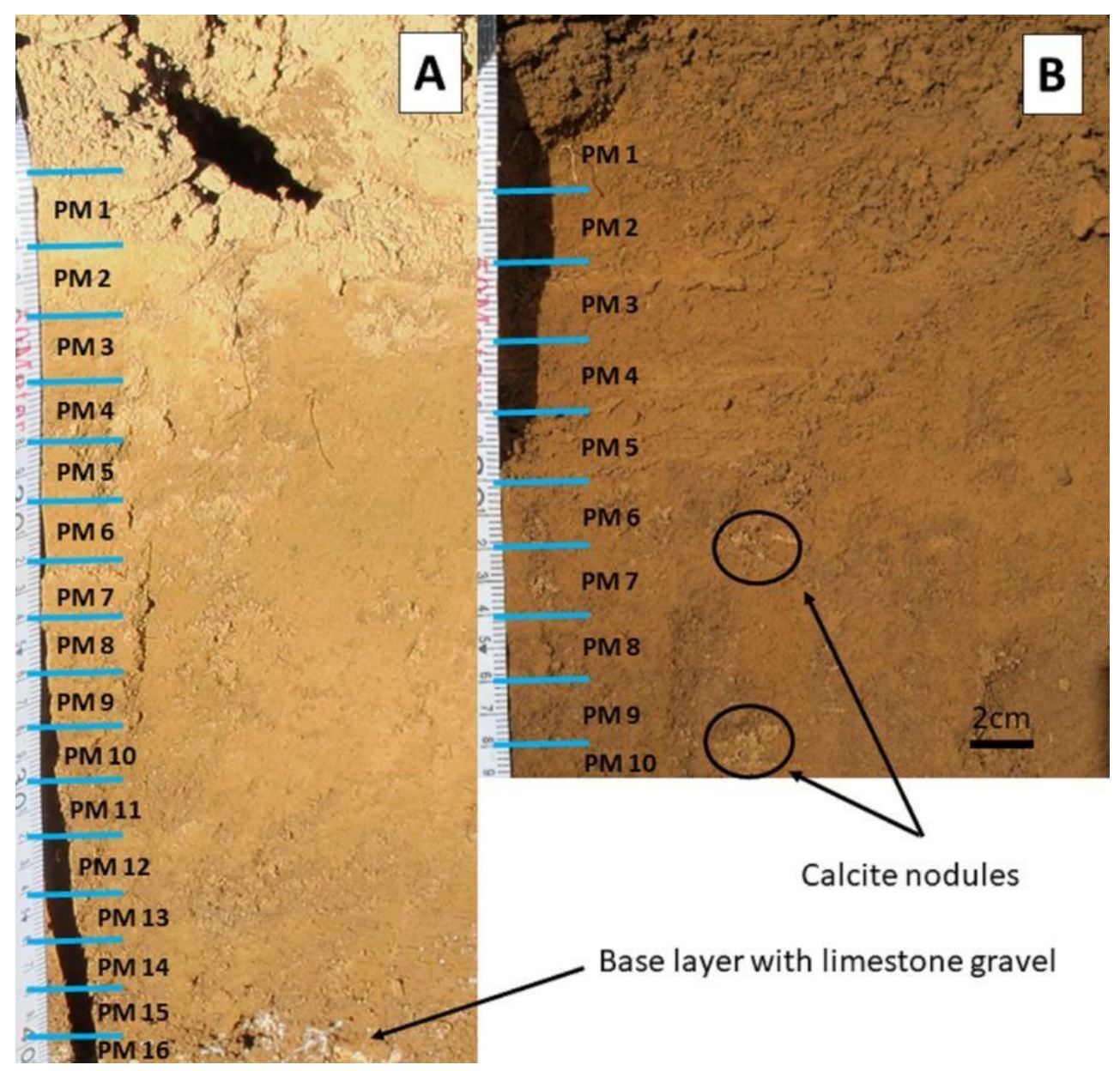

Fig. 3. Pictures of the PM $32 \mathrm{~cm}$ soil loess profile with the respective discrete samples taken every $2 \mathrm{~cm}$. 


\section{HYPOTHESIS AND STUDY DESIGN}

Based on the considerations regarding: the onset of deglaciation Mediterranean mountains at $\sim 12 \mathrm{ka} B \mathrm{P}$ and the termination of the African Humid Period at $\sim 6 \mathrm{ka} \mathrm{BP}$, this study, based on a suite of analytical methods applied to samples from Mount Olympus, Plateau of Muses loess, is challenging the hypothesis that the evolution of Mediterranean alpine loess, occurred along three distinct phases:

i) The postglacial phase, between $\sim 12-10 \mathrm{ka} \mathrm{BP}$, when the alpine domain of Mediterranean mountains entered a phase of postglacial adjustment with large volumes of glacial debris available for deflations, transport and deposition under the influence of snow, water and wind.

ii) The early to mid-Holocene phase between 10 and $6 \mathrm{ka}$ BP when, under a warming and seasonal Mediterranean climate (Peyron et al., 2017), the formation of loess was mainly sourced by local glacial sediments and expanding alluvial planes in lower elevations. iii) The mid to late Holocene from 6 to $0 \mathrm{ka} \mathrm{BP}$, where following the termination of the African Humid period and desiccation of Sahara Desert, along with a change of regional winter climate from Atlantic to Mediterranean, increasing amounts of Sahara dust reached the Mediterranean mountains during episodes of southerly advection.

\section{ANALYTICAL METHODS}

\section{Grain-size analyses}

Grain-size analyses were performed on 21 samples. Five samples were retrieved from distinct clast free horizons of the MK and TZ stratified scree deposits and sixteen samples from the PM loess sequence (Fig. 2B). Samples were wet-sieved through a $350 \mu \mathrm{m}$ sieve and were then analyzed with a Mastersizer 3000 laser diffraction particle size analyzer (Department of Earth Science, University of Bergen, Norway), with a sensitivity of $0.01-350 \mu \mathrm{m}$, to define the bulk grain-size distributions (GSD) of the fine sand to clay fractions. GSD statistical analyses were performed with MATLAB Curve Fitting Lab 
(CFLab), which performs curve fitting on sediment grain size distributions using Weibull Probability Distribution Functions (Wu et al., 2020).

\section{Chemical methods (XRF) and mineral analysis (XRD)}

All samples were analyzed for their bulk mineralogy and geochemistry. The relative elemental composition was determined by X-ray fluorescence using an ITRAX core scanner in the Department of Earth Science of the University of Bergen in Norway. One cubic centimeter of the finer $(<350 \mu \mathrm{m})$ fraction of the samples was air-dried, filled into sample cups and compacted by hand. Four units of 21 sample cups were mounted on sample holders and measurements with the ITRAX XRF core-scanner were performed using a Mo-tube, which can detect a wide range of elements from $\mathrm{Al}$ to $\mathrm{U}$ (Croudace et al., 2006). Counting time was $10 \mathrm{~s}$ and power supply at $30 \mathrm{kV} / 55 \mathrm{~mA}$. XRF spectra were translated into element counts by mathematical peak fitting using Q-spec software (Croudace et al., 2006). Major and trace elements detected by the XRF analyses include $\mathrm{Zr}, \mathrm{Fe}, \mathrm{Ti}, \mathrm{Ca}, \mathrm{Sn}, \mathrm{Mn}$ and $\mathrm{Rb}$ along with the main elements.

$\mathrm{X}$-ray diffraction analyses for the identification of mineral phases of the bulk samples from $\mathrm{MK}, \mathrm{TZ}$ and PM, were performed in the Centre de Recherché et d'Enseignement de Géosciences de l'Environnement (CEREGE) in Aix en Provence, France using a Philips diffractometer (PW1800) with graphite monochromator, Co radiation functioning in $40 \mathrm{kV}, 40 \mathrm{~mA}$. Two samples from the surface and base of the PM sediment profile (PM1 and PM15), were additionally analyzed for the clay $(<2 \mu \mathrm{m})$ mineralogy by subjecting the samples to ethylene glycolation, followed by heating for $2 \mathrm{~h}$ at $550{ }^{\circ} \mathrm{C}$. The PM bulk samples were further processed for their semi-quantitive mineralogical composition, expressed in weight percent (wt\%) in the Department of Mineralogy, Petrology and Economic Geology, School of Geology of the Aristotle University of Thessaloniki in Greece, by using a Philips diffractometer (PW1710) with Ni-filtered $\mathrm{CuK} \alpha$ radiation on randomly oriented samples. The corrections of the wt $\%$ mineralogical compositions were performed using external standard mixtures of the main minerals present scanning under the same conditions, while MAUD-Material Analysis software applied for full 
pattern Rietveld refinement (Lutterotti et al. 2007). Applying these successive steps for the calculation of mineralogical composition, precision of $1 \%$ was achieved (Kantiranis et al., 2011).

\section{Petrographic methods (SEM)}

Petrographic analysis of the PM samples was conducted in the Scanning Microscope Laboratory imaging (Department of Mineralogy, Petrology and Economic Geology, School of Geology of the Aristotle University of Thessaloniki in Greece), focusing on the textural and fabric configuration of the PM sedimentary sequence. The petrographic analyses were performed with a JEOL JSM-840A (Tokyo, Japan) Scanning Electron Microscope (SEM) equipped with an Energy Dispersive Spectrometer - EDS (INCA 250, Oxford) with $20 \mathrm{kV}$ accelerating voltage and $0.4 \mathrm{~mA}$ probe current. Pure Co was used as an optimization element. For the SEM observations, all samples were coated with carbon, with an average thickness of $200 \AA$, using a vacuum evaporator JEOL-4X. Backscattered electron images (BSE) were taken to detect areas of different chemical composition, since the brightness of the BSE image tends to increase with the atomic number of an area. Matrix corrections were made following the standard procedures using a combination of silicate, oxides, and pure metals (wollastonite for $\mathrm{Ca}$ and $\mathrm{Si}$, jadeite for $\mathrm{Na}$, orthoclase for $\mathrm{K}$, corundum for $\mathrm{Al}$, periclase for $\mathrm{Mg}$, metallic $\mathrm{Fe}$ and $\mathrm{Ti}$ for $\mathrm{Fe}$ and Ti).

\section{Magnetic susceptibility (MS)}

The PM samples were subjected to magnetic susceptibility analyses. The samples were sieved to remove all the impurities and packed in cylindrical plastic boxes $(2 \times 2 \times 2 \mathrm{~cm})$. The laboratory measurements of the volume-specific magnetic susceptibility ( $\kappa$, SI units) have been performed using the Barrington MS2B sensor at low and high frequency ( 0.465 and $4.65 \mathrm{kHz}$ respectively). The samples were weighted before each measurement. Here the results are expressed as mass-specific magnetic susceptibility $(\chi$, $10^{-8} \mathrm{~m} / \mathrm{kg}$ ). During the measuring procedure, every sample was measured at least 3 times and the average value was assigned as a measurement. Two air measurements before and after the samples' measurements 
were performed. Additionally, frequency dependent susceptibility $\left(\chi_{\mathrm{FD}} \%\right)$ was calculated according to Dearing et al. (1996) $\left[\chi_{\mathrm{FD}} \%=100\left(\chi_{\mathrm{LF}-} \chi_{\mathrm{HF}}\right) \chi_{\mathrm{LF}}\right]$.

\section{RESULTS}

The PM sediment profile (Fig. 2E) was excavated in the topographical lowest part of the plateau and displays different color and sediment texture characteristics compared to the MK glacial till and TZ scree profiles (Fig. $2 \mathrm{C} \& \mathrm{D}$ ). In the middle of PM profile, at depths between 18 and $16 \mathrm{~cm}$ individual secondary carbonate nodules (calcretes) are present (Fig. 3).

\section{Grain-size analysis}

The grain size distribution (GSD) curves of all samples are polymodal and demonstrate different shapes (Fig. 4A to D) between the different environments (PM, MK and TZ). In total, five grain size modes (M1 to M5) were mathematically derived through the application of CFLab curve fitting algorithm. In all cases, fitting degrees were $>99 \%$ and fitting residuals were $<0.1 \%$, indicating excellent fitting of the raw GSD curves (Fig. $4 \mathrm{E}$ to H). As shown in Fig. 4, the application of CFLab algorithm makes it easy to determine relatively separated modes. In the case of overlapped modes (for instance, M1 and M2), several trial-and-error fittings were undertaken, and a significant increase of fitting residuals was observed when the minor modes M1 or M5 were ignored. These exercises demonstrated the validity and accuracy of the Weibull probability distribution functions in fitting and partitioning the grain size components of polymodal sediments.

The clast free horizons from MK glacial till and TZ scree deposits are coarser compared to PM loess grain size distributions (Fig. 4 A to D). The GSD curves of PM loess contain four grain size modes (M1, M2, M3 and M5). The finer grain size modes, M1 and M2, are in range of clayey silt and appear either in very low concentrations $(<5 \%)$ or are entirely absent from MK and TZ samples (Fig. 4I to L). M1 and M2 with respective grain size of $\sim 2$ and $\sim 4 \mu \mathrm{m}$, account for $40 \%$ of the modal composition in the 
lower layer of PM loess. Their contribution is reduced to $25 \%$ in the upper layer, with minimum values near the surface (Figs 4A \& B). M3 is composed of fine silt and has an average modal size of $\sim 15 \mu \mathrm{m}$ (Fig. 4I to L). M3 is the most dominant mode of PM loess, with average concentrations of $~ 55 \%$ in the lower and $\sim 75 \%$ in the upper layers (Fig. 5C). Substantially lower concentrations of M3 occur in TZ (18\%) and MK (9\%) samples (Fig. 4 K \& L). Grain size mode M4 falls in the range of fine sand, with a modal size of $83.5 \mu \mathrm{m}$ and high $(\sim 50 \%)$ concentrations under the TZ and MK headwalls, while it is entirely absent from PM loess. The coarsest grain-size mode M5 is present in all samples, with an average modal size of $440 \mu \mathrm{m}$. The concentration of M5 is very low $(\sim 5 \%)$ in PM loess, while the opposite holds truth for TZ and MK samples, where M5 constitutes 20\% and $\sim 4 \%$ of the GSD modal composition. The grain sizes of M4 and M5 can be directly linked to frost weathering of the carbonate bedrock. Such observation is in agreement with experimental results of quartz bedrock frost weathering between -12 and $+15^{\circ} \mathrm{C}$ that yielded grain sizes between 500 and $63 \mu \mathrm{m}$, with a mean grain size of $180 \mu \mathrm{m}$ (e.g. Smith et al., 2002).
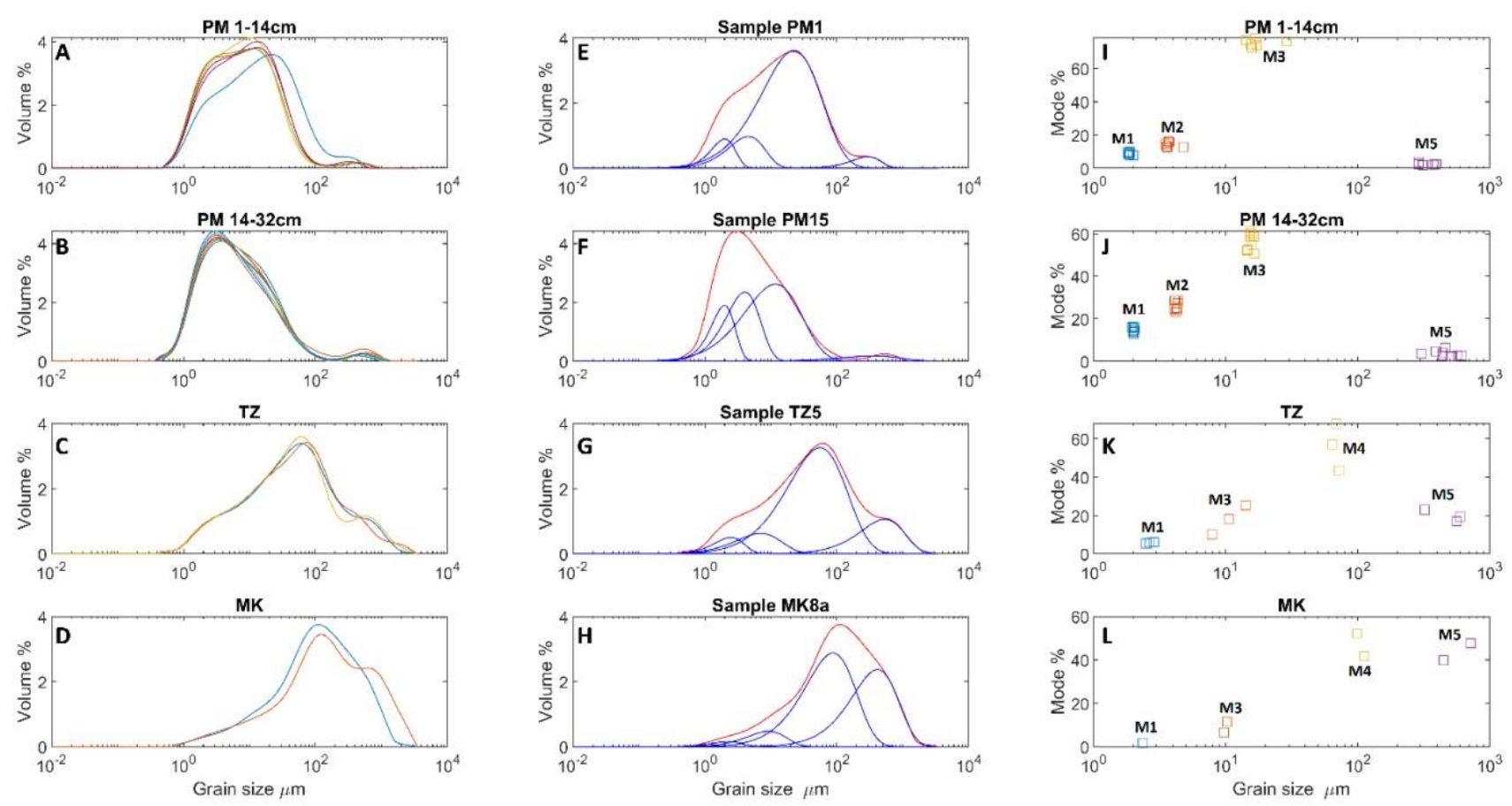

Fig. 4. Results of the CFLab fitting algorithm with the respective grain size frequency distributions (GSD) and extracted grain size modes of selected samples from: (A) the upper ( $>14 \mathrm{~cm}$ profile depth), and (B) the lower $(<14$ cm profile depth) layers of the PM loess profile; (C) TZ and (D) MK clast free horizons. (E) Sample PM1 GSD; 

contributions of: (I) PM loess upper (>14 cm) layer; (J) PM loess lower $(<14 \mathrm{~cm})$ layer; $(\mathrm{K}) \mathrm{TZ}$ and $(\mathrm{L}) \mathrm{MK}$ samples, respectively.

The depth variations of PM loess fine fractions exhibit a contrasting pattern. M1 and M2 display an upward decrease in their respective grain size and modal concentration (Fig. 5A, B, E \& F). The upwards fining of M1 and M2 along with the decrease of their concentrations, may result from either a decrease in the transport capacity from the source, or from a decrease of their in-situ production. A fine mode with a respective grain-size of $\sim 3 \mu \mathrm{m}$, has been reported in almost all European loess representing either regional, or supracontinental sources (Bosq et al., 2020). This may be the case for either M1 and/or M2, with their origin derived either from local sources such the glacial debris and/or the adjacent alluvial plane of Katerini. However, the production of fine particles within the PM catchment from carbonate dissolution and pedogenic processes and their transport to the lower topographic points should not be excluded. The combination of pressure solution in the limestone replacement zone that produces red clays, and of chemical dissolution of limestone bedrock to form coarse sandy debris (e.g. Merino and Banerjee, 2008), are effective mechanisms that can contribute significant amounts of fine particles (i.e. M1 and M2) to PM loess sequence. In contrast to M1 and M2, the modal contribution of M3 is increasing upwards (Fig. 5C), with no changes in its grain-size along the entire profile (Fig. 5G). M3 percent concentration shows a gradual increase in the lower layer, followed by an abrupt (15\%) increase between 14 and $16 \mathrm{~cm}$ of profile depth (Fig. 5C). This most likely reflects an increase of the available material, and/or enhanced transport dynamics from the source area(s). Sandy mode M5 exhibits a coarsening upward trend along the lower layer, intercepted by an abrupt change along the boundary between upper and lower layers, at 16-14 cm depth (Figs 5D \& H), with an overall decrease in its modal concentration. 

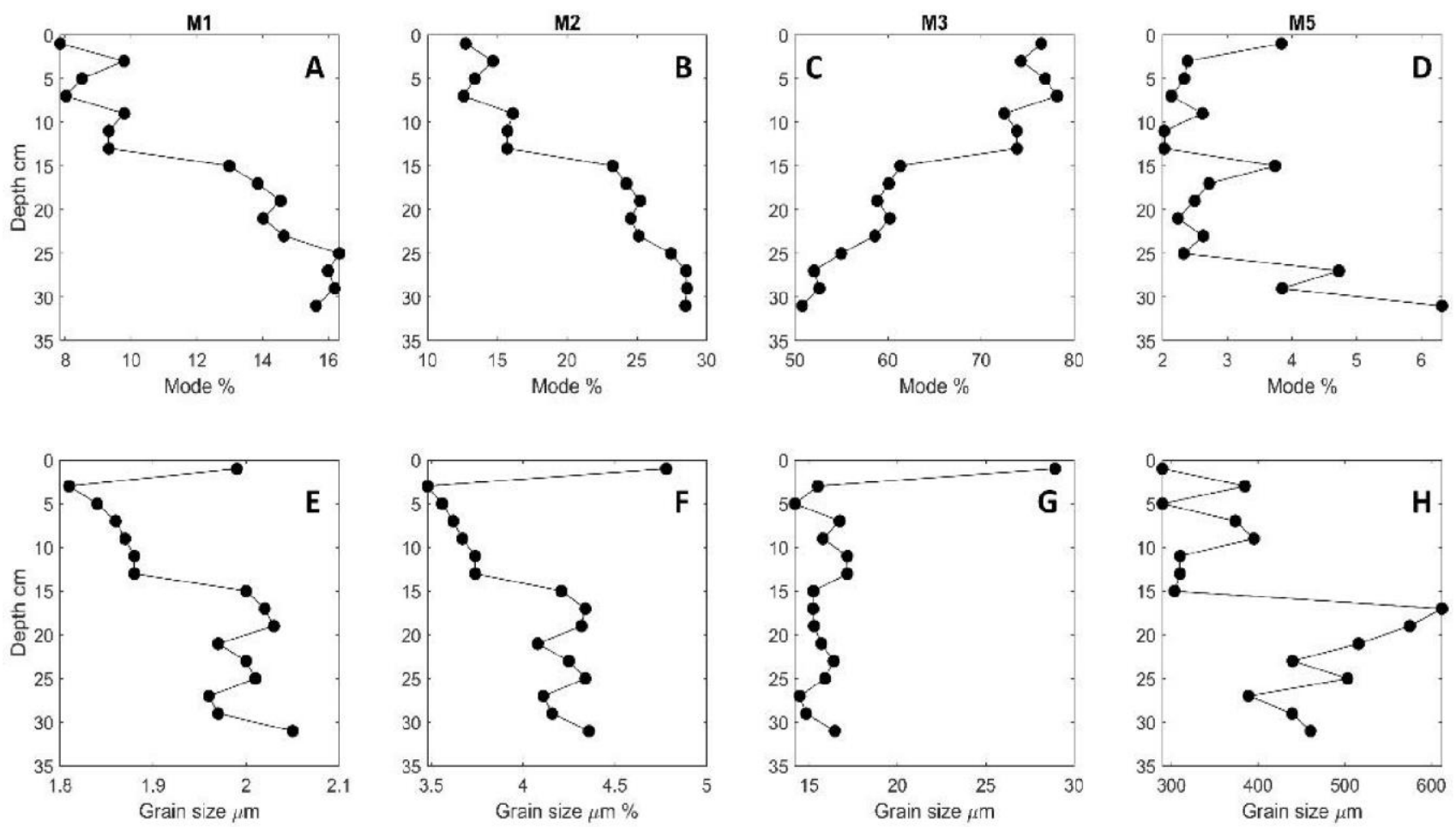

303 Fig. 5. PM sediment profile depth variations in the contributions of grain-size modes M1, M2, M3 and M5 (A to 304

D), and depth variations of the grain-size of modes M1, M2, M3 and M5 (E to H).

Mineralogy

The X-ray diffraction analyses of the bulk samples identified a mineralogy that differs between MK, TZ and PM sediments. The most dominant mineral phases in the clast free material of MK and TZ deposits are calcite and dolomite (Fig. 6A). Other identified minerals are plagioclase (albite), K-feldspars and clays. On the contrary, the bulk mineralogical composition of PM loess exhibits a richer suite of mineral phases (Fig. $6 \mathrm{~B}$ and C) that include mainly quartz and K-feldspars, plagioclase, iron oxides, micas, amphiboles and a mixed layer of clays. Calcite is dominant ( 50\%) only in basal samples PM15 and 16,

313 along with mixed aluminosilicate faces and Fe-Ti oxides. Quartz and mixed layer clays are the most dominant mineral phases of samples PM1 to PM14 with average wt $\%$ concentration of $\sim 80 \%$, with plagioclase, feldspars and mica represent the remaining $20 \%$. 

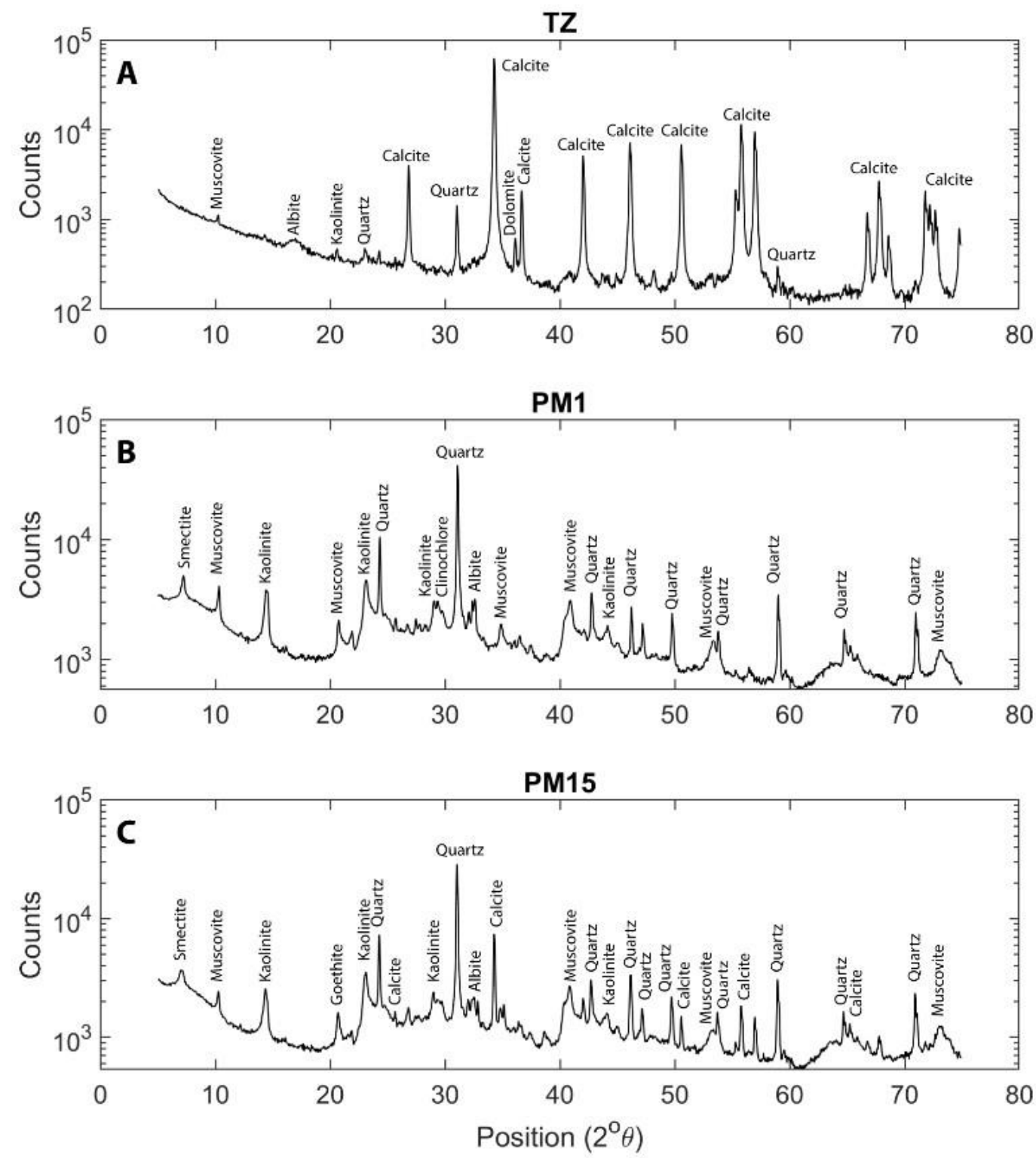

317 Fig. 6. Contrasting patterns of X-ray diffraction results for the sediments of (A) TZ and MK stratified scree clast 318 free horizons and (B) and (C) from PM surficial and basal samples PM1 and PM15. 

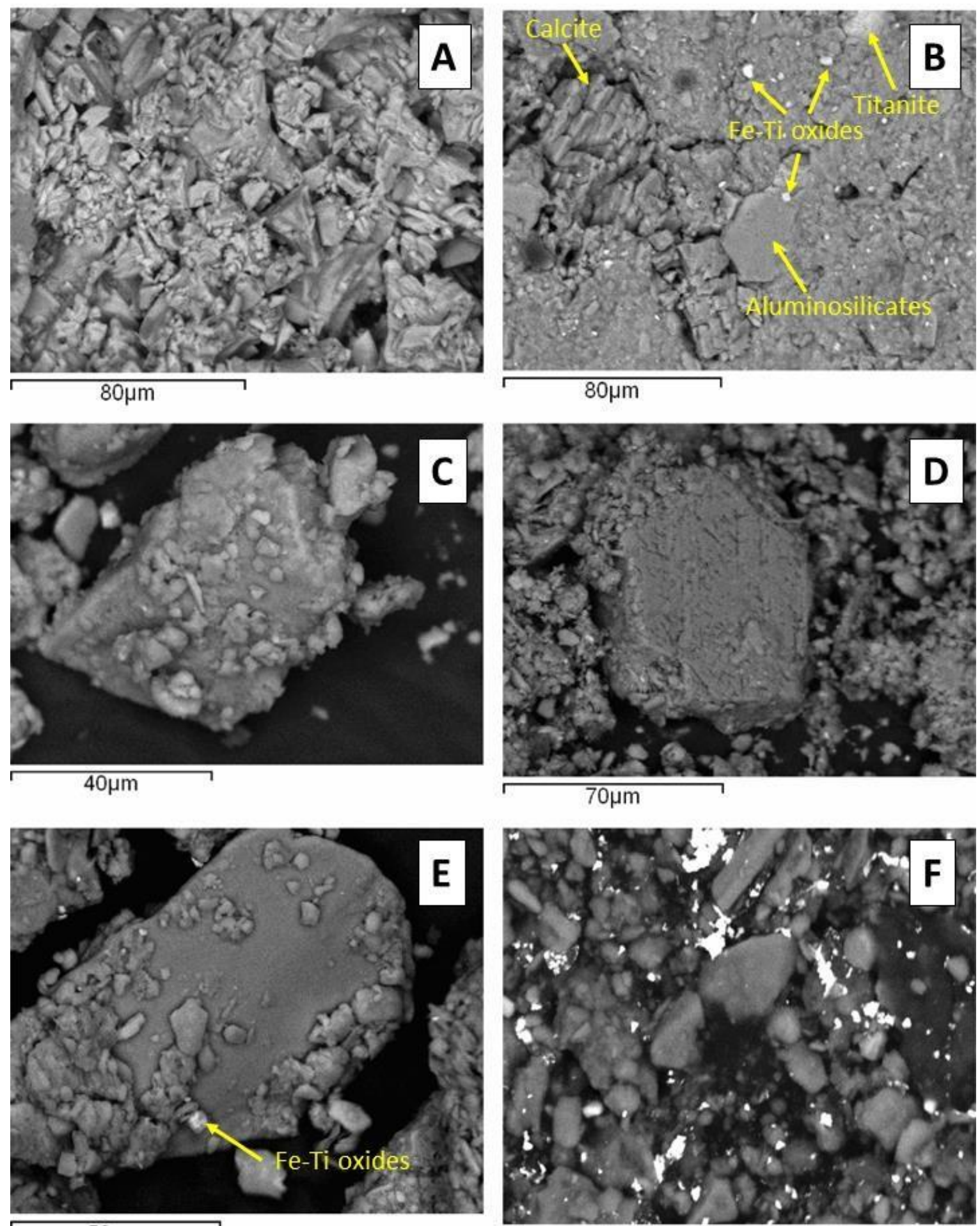

$50 \mu \mathrm{m}$

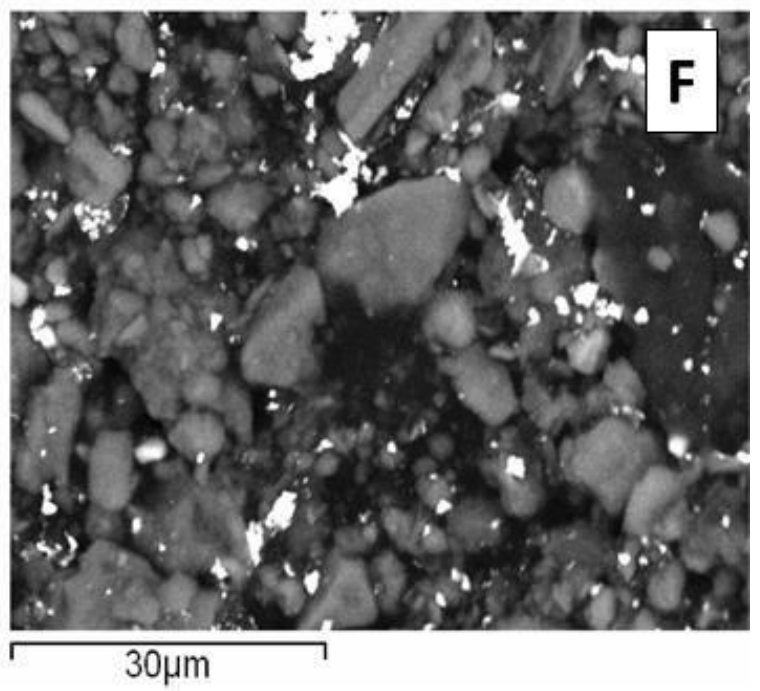

319 Fig. 7. SEM images from selected samples of PM loess profile. (A) Calcite from basal sample PM 16. (B) Mixed

320 phase of aluminosilicates with calcite and Fe-Ti oxides and titanite from basal sample PM 16. (C). K-feldspar. (D)

321 Albite. (E) Surface sample PM1 aggregate of aluminosilicates and Fe-Ti oxides. (F) Quartz grains from sample

322 PM3 
SEM image analyses of PM loess samples, illustrate the dominance of mixed phases, composed of aluminosilicates, clay minerals and Fe-Ti oxides. These mixtures form aggregates present along the entire profile (Figs 7A, B, E). Fe and Ti are low mobility elements especially in oxidizing environments with $\mathrm{pH}$ values above 4.5 , so they are not affected by element translocation during weathering (Buggle et al., 2008). Their presence throughout PM loess profile suggests a detrital origin from bedrock formations. Highly magnetic Fe-Ti oxide minerals, such as magnetite and titanomagnetite, commonly intergrown with hematite, ilmenite and ilmenorutile, form originally in igneous rocks during initial cooling (e.g. Reynolds et al., 2001) and here must have been a compartment of Mount Olympus metacarbonates, during the initial stages of their formation. Fe-Ti oxides are incorporated with aluminosilicates and mixed layer clays within aggregates of variable grain sizes (Fig. 7B), that likely form during post depositional processes, but are not represented in the grain size distributions, since they were chemically dissolved during samples preparation. SEM images also suggest that plagioclase (albite) and K-feldspar are also derived from carbonate bedrock weathering, as their grain size $(\sim 80 \mu \mathrm{m})$ falls close to the grain size of modal class M4 (Figs 7C \& D). On the contrary, the ubiquitous presence of quartz in PM loess samples is confined within the fine fractions and suggests a non-detrital origin. Quartz grains display a rounded shape and variable grain sizes smaller than $15 \mu \mathrm{m}$ (Fig. 7F), which imply their presence within M1, M2 and M3 grain size modes, respectively. The rounded shape of quartz grains depicted from the SEM images, likely is a product of long-range aeolian transport.

Clay mineralogy analyses of surficial (PM1) and basal (PM15) samples identified the dominance of smectite and kaolinite, with lesser contributions of chlorite and illite. In sample PM1 smectite (45\%) and kaolinite (35\%) are dominant, with lesser contributions of illite and chlorite (10\%). Basal sample PM15 has higher smectite contents (65\%), with reduced concentrations of kaolinite (25\%) and illite and chlorite (5\%), compared to the surface. Kaolinite is also traced in MK and TZ samples and can either be of detrital origin or formed from the alteration of other bedrock minerals such as plagioclase (albite), a process that is common in glacial and periglacial environments (e.g. Anderson, 2005). Similarly, high amounts of smectite have been found in alpine soils within proglacial fields and result from the alteration 
of detrital or aeolian micas (e.g. Egli et al., 2014). XRD analyses suggest the presence of micas in PM, MK and TZ samples, so the alteration of detrital muscovite is likely an ongoing process on Mount Olympus periglacial environments, but the analyses undertaken here cannot provide further conclusions on secondary mineral formation.

\section{Elemental composition}

The elemental composition of the sediments considered here is expected to reflect their mineralogy and provides an additional tool to discriminate the relative sources of $\mathrm{MK}$, $\mathrm{TZ}$ and $\mathrm{PM}$ depositional environments. $\mathrm{Ca}$ is the dominant element in the $\mathrm{MK}$ and $\mathrm{TZ}$ samples, while $\mathrm{Fe}$ is the most abundant element in the PM samples. Along with $\mathrm{Ca}, \mathrm{Sn}$ is also present in MK and TZ samples, but barely detectable in the PM loess (Fig. 8B). Sn bearing sulfides exist in metacarbonates in southern Greece and are formed by carbonate replacement during exhumation (e.g. Voudouris et al., 2008). Sn presence in the metamorphosed Cretaceous limestones of Mount Olympus may thus reflect its uplift and exhumation history. The minimal Sn counts in PM samples (Fig. 8B) are explained by the slow mobility of Sn during weathering (Kabata-Pendias, 2001), whereas low Ca counts likely result from decalcification of the loess profile, a process common in other loess deposits (e.g. Bosq et al., 2020). Mn and Rb are also present in MK and TZ samples (Fig. 8 D and E) and appear enriched in PM loess. Mn has been found in manganese rich shale bands of the North Calcareous Alps (e.g. Rantitsch et al., 2003), which may be the case for Mount Olympus, as interbedded shale bands are visually observed within the cirques' headwall Cretaceous limestones. $\mathrm{Rb}$ shows similar behavior with $\mathrm{K}$, but is less mobile (Bosq et al., 2020) and is generally hosted K-feldspars, micas and clays (Nesbitt et al., 1980), which constitute integral compartments of Mount Olympus bedrock. Thus, it is safe to consider that the Mn and Rb enrichment of PM loess (Fig. 8D \& E) results from sorting during catchment erosion. Besides $\mathrm{Fe}, \mathrm{Ti}, \mathrm{Mn}$ and $\mathrm{Rb}$, $\mathrm{PM}$ loess is additionally enriched in $\mathrm{Zr}$ and $\mathrm{Cr}$, which appear in negligible quantities in $\mathrm{MK}$ and $\mathrm{TZ}$ samples (Fig. 8E to H), so their origin from mechanical weathering of bedrock, is implausible. An alternative mechanism for their transport and deposition in PM loess is deflation from distal or local sources, such as the Sahara Desert, the proximal ophiolitic Pieria Mountains and Katerini alluvial plane. 

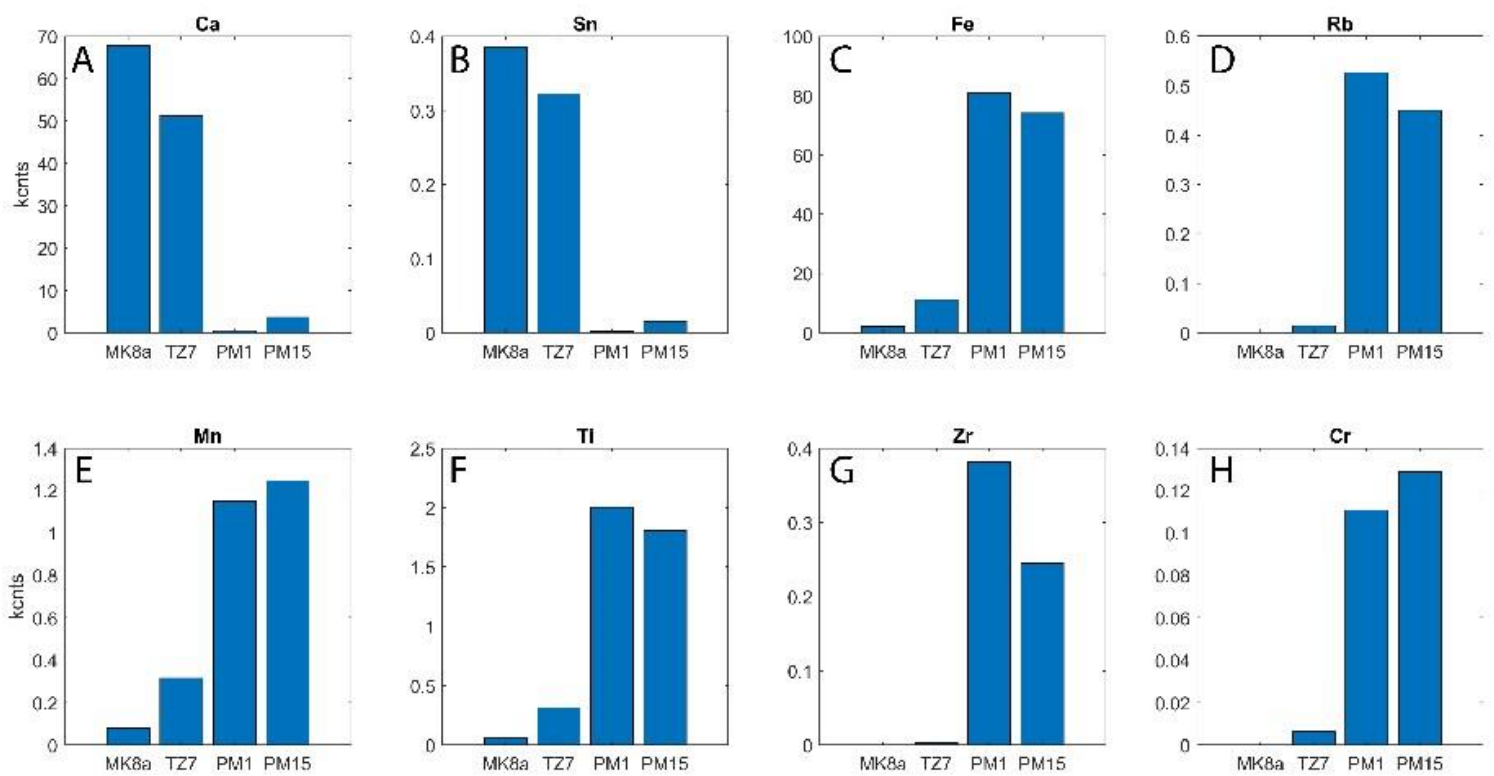

Fig. 8. Elemental differences between selected samples representing the contrasting sedimentary environments of PM, TZ and MK.

\section{Magnetic susceptibility}

The mass-specific magnetic susceptibility profile of PM loess reflects changes in grain size and mineralogy between stages of loess deposition and when climatic conditions favored pedogenesis. The lower layer of PM loess $(32-16 \mathrm{~cm})$ is characterized by higher low frequency magnetic susceptibility ( $\chi \mathrm{lf}$ ) with a mean value of $55 \times 10^{-8} \mathrm{~m}^{3} \mathrm{~kg}^{-1}$. On the contrary, lower $\chi$ lf values are found in upper layer, with a mean value of $36 \times 10^{-8} \mathrm{~m}^{3} \mathrm{~kg}^{-1}$ (Fig. 9A) and occur concurrently with a reduction in M1 and M2 concentrations and with a decrease of the Fe/Ti ratio (Fig. 9B \& C). Higher $\chi$ lf values in the PM loess lower layer can be attributed to increasing abundance of stable single domain (SD), pseudo single domain (PSD), and multi domain (MD) grains (e.g. Költringer et al., 2020). The frequency dependence of magnetic susceptibility ( $\chi \mathrm{fd}$ given in $\%$ ), has respective mean values of $3.6 \%$ for the lower and $8.6 \%$ for the upper layers, respectively (Fig. 9D). Due to its sensitivity to super paramagnetic (SP) particles, $\chi \mathrm{fd}$ is often used to identify ultrafine-grained iron oxide formation e.g., magnetite, maghemite, and hematite during pedogenesis (e.g. Maher, 2011). Dearing et al., (1996), suggests that samples dominated by multi domain grains (MD), show relatively high $\chi \mathrm{lf}$ but $\chi \mathrm{fd}$ close to zero. Values of $\chi \mathrm{fd}<5 \%$ are 
inferred to be typical for samples containing stable single domain (SD) grains, or a very fine $(<0.005$ $\mu \mathrm{m}) \mathrm{SP}$ fraction. Samples dominated by SP grains, show $\chi \mathrm{fd}$ of $10 \%$ and more. In this context, the $\chi \mathrm{fd}$

398

399

400

401

402

403

values of the lower layer of PM loess point towards the presence of MD and stable SD grains, while the upper layer appears to be enriched in SP grains, implying that during deposition of PM loess upper layer conditions on Mount Olympus were favorable to pedogenesis. The upwards increase of $\chi \mathrm{fd}$ coincides with an increase in M3 concentration (Fig. $9 \mathrm{D} \& \mathrm{E}$ ) and with a decrease of the K/Rb ratio (Fig. 9F), which is a proxy for post depositional weathering of $\mathrm{K}$ (Buggle et al., 2011) and likely results from post depositional weathering of PM loess.
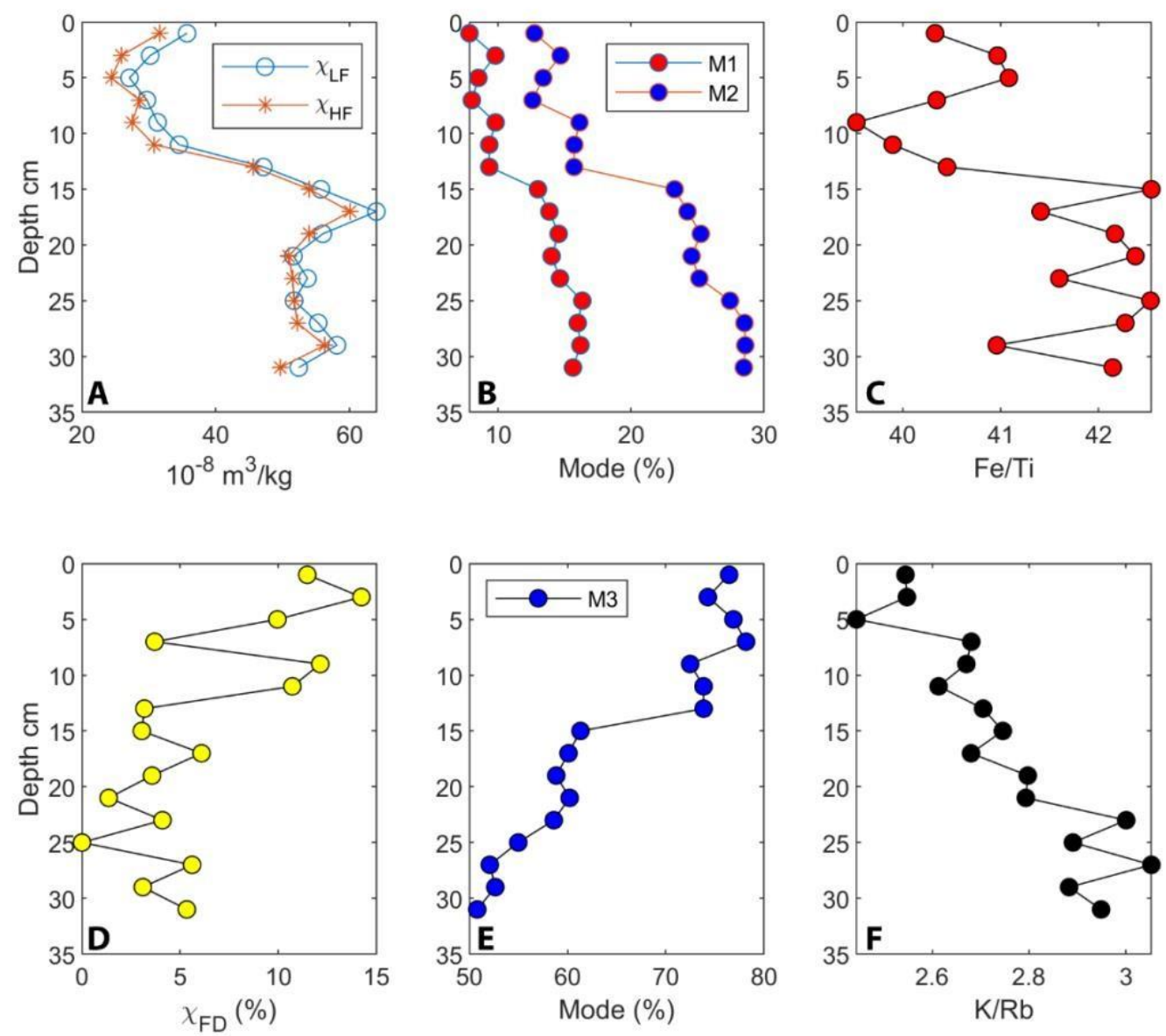

404

405 Fig. 9. (A) Depth variations of low and high frequency magnetic susceptibility, along with M1 and M2 406 concentrations (B), Fe/Ti ratio (C), frequency depended magnetic susceptibility (D), M3 concentration and chemical weathering proxy $\mathrm{K} / \mathrm{Rb}(\mathrm{F})$. 


\section{Local weathering}

410 The low correlation between M5 grain size and the Ca XRF counts among all samples $(\mathrm{r}=0.45, p<$

$4110.05, \mathrm{n}=21$ ), contrasts the notion that the coarse rich sands, are only produced by physical weathering

412 of bedrock carbonate formations. The low correlation can be attributed to dissolution kinetics and

413 leaching of Ca during disintegration of carbonate bedrock to gravel and sand. Within PM loess sequence,

414 the positive correlation between M1 and M2 concentrations with M5 grain-size $(\mathrm{r}=0.67, p<0.05)$,

415 suggests that the production of coarser sandy debris is associated with higher concentrations of fine

416 particles. A physical mechanism that can explain this statistical relationship is the isovolumetric

417 replacement of Ca-rich sand to clay, as proposed by Merino and Banerjee (2008). Thus, the formation

418 of M1 and M2 depends, at least partially, on the availability of carbonate sands of environmental

419 conditions that either favor frost cracking and mechanical disintegration of bedrock, and/or post 420 depositional weathering of the eroded grains.

422 On the other hand, between M1 and M2 concentrations, low ( $\chi \mathrm{lf})$ and high ( $\chi \mathrm{hf})$ magnetic susceptibility and Fe/Ti ratio, a proxy for iron rich clay variations in alpine soils (Muhs et al., 2001), show high positive correlations $(\mathrm{r}>0.7, p<0.001)$ and display higher values in PM loess lower layer. In general, high values of magnetic susceptibility in loess sequences result from enrichment of ferromagnetic minerals during pedogenesis (Zhou et al., 1990; Maher and Thompson, 1992; Heller and Evans, 1995), but the high values $(>10)$ of frequency dependent magnetic susceptibility ( $\chi \mathrm{fd})$, in the upper layer of PM loess (Fig. 9D), contrast this notion. In addition, similar Fe/Ti ratio values between PM loess (42) with MK (36) and TZ (35) samples confirm the presence of Fe-Ti oxides in carbonate bedrock formations and supports their detrital and not pedogenic origin. Thus, the high correlations between $\chi \mathrm{lf}, \mathrm{M} 1$ and $\mathrm{M} 2$ with Fe/Ti ratio imply that weathering of bedrock and subsequent release of Fe-Ti oxides, such as titanomagnetite, ilmenite and hematite, control the magnetic signal of PM loess. The formation of coarser aggregates is attributed to post depositional processes, whereas the exhaustion of glacial carbonate debris evident from the reduced concentration and fining of the coarsest grain size mode M5

(Fig. 5D \& H), resulted, to an unknown extend, in the reduction of M1 and M2 and hence to the lower $\chi$ lf and $\chi$ hf values. Because Fe and Ti vary together $(r=0.95, p<0.001)$, their ratio also permits to 
evaluate the possible loss of $\mathrm{Fe}$ to $\mathrm{Ti}$ via dissolution. The decrease in Fe/Ti ratio in the upper layer (Fig. 9C), may result from the post-depositional dissolution of ferromagnetic oxides, mainly magnetite and hematite. Overall, the reduction in the grain size and concentration of modes M1 and M2 (Fig. 5), is linked to the exhaustion of carbonate debris supply and occurred during conditions favorable to pedogenesis, as indicated by the upper layer increasing $(>5 \%) \chi \mathrm{fd}$ values that favored the dissolution of Fe-Ti oxides and subsequent removal of Fe from PM loess. Similar patterns have been found in Holocene loess-paleosol sequences along the NW Chinese loess plateau, where the contrasting behaviour between $\chi \mathrm{lf}$ and $\chi \mathrm{fd}$ have are attributed to the formation of nonferrimagnetic minerals associated with waterlogging (Chen et al., 2012). If this has been the case for PM loess, it is argued that extended snowcover and/or wet summer conditions during the deposition of PM loess upper layer, likely induced waterlogged conditions which forced the observed pedogenic depletion of Fe (deferrification).

\section{Aeolian dust sources}

The local dust sources of Mount Olympus are the exposed glacial and periglacial landforms, the Pieria mountaintops, which with an elevation of $2200 \mathrm{~m}$ were likely affected by the late glacial erosion and the alluvial plain of Katerini (Fig. 2A). Mount Olympus glacial and periglacial landforms are rich in carbonate sand, whereas ultramafic sediments eroded from Pieria Mountains ophiolitic formations are deposited in the alluvial plane of Katerini. On the contrary, Sahara dust mineral composition is rich in quartz, phyllosilicates and clays (Brooks et al., 2005), but also in crustal heavy minerals such as Ti and Zr (Moreno et al., 2006; Aarons et al., 2013; Scheuvens et al., 2013). Zr and Ti usually vary together in sediments because they are chemically immobile and in alpine soils have been used as proxies of detrital heavy minerals (Muhs et al., 1990). However, the low correlation between $\mathrm{Ti}$ and $\mathrm{Zr}(\mathrm{r}=0.55, p<0.03)$, implies that the origin of $\mathrm{Zr}$ and $\mathrm{Ti}$ in $\mathrm{PM}$ loess is likely different. Ti results from the mechanical weathering of carbonate bedrock and is deposited in the PM loess sequence in the form of Fe-Ti oxides occurring within mixed aggregates, while $\mathrm{Zr}$ is mainly transported in Mediterranean alpine systems during episodes of Sahara dust transport (e.g. Jimenez-Espejo et al., 2014). The nearly zero 
concentrations of $\mathrm{Zr}$ in $\mathrm{MK}$ and $\mathrm{TZ}$ samples, rules out its detrital origin and supports the mechanism of $\mathrm{Zr}$ aeolian enrichment in PM loess.

Within PM loess profile, the weight percent (wt\%) concentration of mica and Zr XRF counts, display high correlations $(r>0.70, p<0.003)$ with M3 concentration. This relation argues that additionally to mica (muscovite) presence in bedrock formations (TZ and MK samples) depicted from XRD spectra, micaceous silt grains are also transported during Sahara dust episodes. The range of the M3 mean grain size ranges between 14 and $28 \mu \mathrm{m}$ and is similar to modern values Sahara dust modal and median grain sizes from Crete (Fig. 1), which range between 8 and $30 \mu \mathrm{m}$ (Goudie and Middleton, 2001) and 4 to 16 $\mu \mathrm{m}$ (Mattson and Niéhlen, 1996), respectively. Thus, it is reasonable to support that M3 can be considered a representative grain size mode of Sahara dust contribution to PM loess.

However, rounded quartz grains occur in a variety of grain sizes from 2 to $15 \mu \mathrm{m}$ (Fig. 7F), which is also supported by the correlation between the sum of M1, M2 and M3 modal concentrations with quartz ${ }_{\mathrm{wt}} \%(\mathrm{r}=0.74, p<0.001)$. This suggests that transport of Sahara dust to Mount Olympus includes finer particles in clayey silt range, assuming that all aeolian quartz comes from Sahara region. Since quartz is traced in minor quantities in MK and TZ samples (Fig. 5A), the conclusion that the finer modes M1 and M2 contain aeolian components, either from Sahara, or from local sources (Pieria Mountains and Katerini alluvial plane), is valid, but the exact origin of quartz cannot be defined from the existing analyses. Therefore, synergistic to the weathering of Mount Olympus carbonates and deposition of detrital components with subsequent post depositional production of fine particles and aggregates rich in Fe-Ti oxides, is the deposition of fine dust incorporated into M1 and M2. Background dust with grain size similar to M1 and M2 $(\sim 3 \mu \mathrm{m})$, is found in many European loess sequences and represents local, regional, or supracontinental sources (Bosq et al., 2020). Deflation and deposition of fine particles from Pieria Mountains and Katerini alluvial plane on Mount Olympus and their contribution to M1 and M2 composition, are supported by the strong $(r>0.85)$ correlations between M1 and M2 concentrations with $\mathrm{Cr}$ and $\mathrm{Ni}$, which are elements representative of ultramafic rocks. The source of $\mathrm{Cr}$ and $\mathrm{Ni}$ can be deflated ophiolitic sediments either deposited by periglacial activity on the mountaintops of Pieria 
Mountains or transported by fluvial action to the proximal Katerini alluvial plain. The respective correlations between M1 and M2 concentrations with $\mathrm{Cr}$ and Ni, are high only along the lower $(>16 \mathrm{~cm})$ layer of PM loess. The reduction of $\mathrm{Ni}$ and $\mathrm{Cr}$ along the upper layer is concomitant with the reduction of M1 and M2 concentrations, but the partitioning of deflation sources between, background aeolian dust, Mount Olympus glacial landforms, and the reworked sediments from Pieria Mountains and Katerini alluvial plane, to the geochemical contribution M1 and M2 is difficult to discern.

\section{Post depositional alteration}

It widely accepted that in proglacial fields and alpine soils secondary clay mineral formation through alteration of mica to smectite (Egli et al. 2003) and plagioclase to kaolinite (Anderson et al., 2000) occurs in rates similar to non-glacierized catchments (Anderson, 2005). Given the significant (>30\%) contributions of smectite and kaolinite in the clay $(<2 \mu \mathrm{m})$ fraction of samples PM1 and PM15, the possibility of post depositional alteration of mica to smectite and of plagioclase to the formation of kaolinite, cannot be excluded for PM loess. Higher concentrations of chemical weathering products (smectite and kaolinite) in the base of PM profile (sample PM15), compared to the surface sample (PM1), enhance the view of enhanced mineral alteration towards the base of the profile. However, significant concentrations ( 12\%) of kaolinite in the sediments of north Aegean Sea core SL148 and its crystallinity characteristics, have characterized kaolinite as a proxy for Sahara dust input (Fig. 10B), (Ehrmann et al., 2007). So, the exact origin of kaolinite within PM loess clay fraction, either detrital, aeolian, or formed through plagioclase weathering, cannot be accurately defined here.

In terms of both proglacial sediments and loess weathering dynamics, the early stage of Ca removal, is followed by the intermediate stage of K removal and by the final stage of Si removal (e.g. Anderson et al., 2000; Hošek et al., 2015). In Aquitaine, southwest France, decalcification of loess has been attributed to syn or post-depositional Ca removal and is described by the $\mathrm{Ca} / \mathrm{Sr}$ ratio (Bosq et al., 2020). $\mathrm{Ca} / \mathrm{Sr}$ decreases with increasing intensity of Ca weathering (Bokhorst et al., 2009) and within PM loess it ranges from 8 to 2 from the base towards the surface of the PM profile. These values are considerably lower compared to the respective values of the $\mathrm{TZ}(\mathrm{Ca} / \mathrm{Sr}=89)$ and $\mathrm{MK}(\mathrm{Ca} / \mathrm{Sr}=189)$ sediments. $\mathrm{Ca} / \mathrm{Sr}$ 
is significantly positively correlated with the finer modes M1 and M2 ( $r>0.6)$, which could be explained by the fact that decalcification of PM loess, largely occurs within the finer fractions, with subsequent replacement of calcite to the formation of clay particles and mixed aggregates found in SEM images

522

523

524 (Fig. 7).

The observed $\mathrm{Rb}$ enrichment in PM, compared to MK and TZ samples (Fig. 6D), results from the weathering of K-bearing minerals, such as mica (e.g. Anderson et al., 2000; Hošek et al., 2015; Zech et al., 2008). In the previous section, it is argued that in addition to its detrital origin, mica is an inherent component of Sahara dust transport to Mount Olympus and is identified in small concentrations ( $6 \%)$ in PM loess. The loss of mica to smectite cannot be quantified, but it appears that after its initial deposition, mica is subjected to post depositional weathering with removal of $\mathrm{K}$ (Buggle et al., 2011, Bosq et al., 2020). This is supported by the low values of $\mathrm{K} / \mathrm{Rb}$ elemental ratio (Fig. 9F), used on many occasions to describe the weathering intensity and removal of $\mathrm{K}$ from loess deposits (Profe et al., 2016). Similar to $\mathrm{Ca} / \mathrm{Sr}$ ratio, $\mathrm{K} / \mathrm{Rb}$ values in PM loess are considerably lower (2.7) compared to $\mathrm{TZ}$ (45) and MK (228) sediments and show high correlations ( $r>0.85$ ) with M1 and M2 concentrations, suggesting that intense weathering and production of fine particles occurs within PM loess. This likely explains the low concentration of fine modes within the MK and TZ clast free horizons since the chemical weathering conditions under the cirque headwalls are low due to extensive snow cover, slope steepness, aspect, and high production rates of coarse carbonate debris that enhances percolation of snowmelt. Translocation of clay particles in the coarse matrix of glacial till and stratified scree deposits may also be responsible for the minor contents of fine particles, but the assessment of these factors is beyond the scope of this study.

\section{Relative chronology of PM loess}

The main step in establishing the relative chronology of PM loess deposition is to constrain the transition period between the upper and lower layers from 14 to $16 \mathrm{~cm}$ of profile depth that partition several sedimentological and geochemical changes. The 15\% increase of M3 concentration along the transition layer (Fig. 4C), suggests a growth in Sahara dust availability that can be associated with the midHolocene termination of the African Humid Period (AHP; 10-6 ka BP) and the regional climatic 
shift from Atlantic- to Mediterranean dominated with enhancement of southerly air flows. Several studies

549

550

551

552

553

(e.g., Magny et al., 2013, Perșoiu et al., 2017, Zielhofer et al., 2017b) have suggested a major reorganization of winter atmospheric circulation patterns across Europe during the mid-Holocene (coincident with the termination of the AHP), with the negative phase of the North Atlantic Oscillation (NAO) dominating before $\sim 6$ to $5 \mathrm{ka} \mathrm{BP}$ and the positive phase, after $\sim 6$ to $5 \mathrm{ka} \mathrm{BP}$. The NAO controls the delivery of moisture from the Atlantic Ocean to mainland Europe (Hurrel et al., 2013) in winter. During NAO- periods, the low pressure difference between the Icelandic Low and the Azores High result in southward deflected westerlies across Europe and associated high values of winter precipitation, while during the NAO+ phase, the high difference between the two pressure systems deflects the westerlies northwards, leaving southern Europe dry. The stronger than usual Azores High active during NAO+ periods further lead to increased advection of air and dust from Sahara towards southern Europe. Dexcess values in cave ice in East-Central Europe (ECE) indicate the intensification of Mediterranean winds after $\sim 6 \mathrm{ka} \mathrm{BP}$, further supporting strengthened southerly advection of air over SE Europe. The above, tentatively place the boundary between PM loess upper and lower layers at $\sim 6 \mathrm{ka} \mathrm{BP}$. Throughout the literature, $\mathrm{Zr}$ concentrations expressed by the $\mathrm{Zr} / \mathrm{Th}$, or the equivalent $\mathrm{Zr} / \mathrm{Al}$ ratios, have been used as a proxy of Sahara dust input in the Mediterranean region (Jimenez-Espejo et al., 2014 and references therein). In Central Mediterranean marine core ODP 964 (Fig. 1), the $\mathrm{Zr} / \mathrm{Al}$ ratio along with the wt\% concentrations of kaolinite and palygorskite, have been also used as a Sahara dust proxy, with generally lower values during past AHP (e.g. Gallego-Torres et al., 2007). Kaolinite content is also used as a proxy of Sahara dust influx in the north Aegean Sea core SL-148 (Ehrmann et al., 2007). Further chronological constrains on the PM loess depositional history are achieved through the visual correlation of $\mathrm{Zr} / \mathrm{Al}$ ratio of PM loess with the respective $\mathrm{Zr} / \mathrm{Th}$ ratio from Laguna De Rio Seco in the Spanish Pyrenees (JimenezEspejo et al., 2014) and with the kaolinite concentrations of north Aegean marine core SL 148 (Ehrmann et al., 2007).

The curve similarity of the three profiles shown in Fig. 10, tentatively confirms the previous consideration that the transition period between the lower and upper layers of PM loess broadly coincides 
with the termination of African Humid Period at $\sim 6 \mathrm{ka}$ BP. A subsequent peak in Sahara dust transport around $4.5 \mathrm{ka} \mathrm{BP}$ marks the upper boundary of this transition layer. Of particular interest is the temporal constrain of the profile base with the relative date of sample PM3 placed $10 \mathrm{ka}$ BP. This implies that the calcite rich samples PM1 and PM2 were deposited during the initial stages of Mount Olympus deglaciation phase, between 12 and $10 \mathrm{ka} \mathrm{BP}$, in agreement with the stabilization of moraines in $\mathrm{TZ}$ 580 cirque (Fig. 2A). During this phase, influx of meltwater from the retreating cirque glaciers provided 581 aggressive solutions that were reacting with the carbonate bedrock dissolving it in high rate.

582 A further implication that can be derived from chronological constrain of PM loess, concerns the pedogenetic conditions between 6 and 0 ka BP. During this period, lower concentrations of the finer modes M1 and M2, lower magnetic signal and decreased values of $\mathrm{Fe} / \mathrm{Ti}$, suggest that pedogenesis was induced by wetter than present summer conditions, which are confirmed from pollen based climatic reconstructions validated by a regional climatic model (Peyron et al., 2017). Broadly speaking, an additional feature that can be deduced from the relative chronology of PM loess profile concerns its average sedimentation rate. Niéhlen et al. (1995), conclude an average Holocene deposition rate of Sahara dust of $\sim 2 \mathrm{~cm} / \mathrm{ka}$, which is close to $\sim 2.5 \mathrm{~cm} / \mathrm{ka}$ derived from for the upper layer of PM loess. The remaining $\sim 0.5 \mathrm{~cm} / \mathrm{ka}$ should represent the contribution of local weathering, as supported by a recent

591 study, which is based on ${ }^{36} \mathrm{Cl}$-inferred denudation rates from western Mediterranean mountains and 592 suggests average weathering rates of $0.3-0.6 \mathrm{~cm} / \mathrm{ka}$ during the last glacial / interglacial cycle $(5-40 \mathrm{ka}$ BP, Thomas et al., 2018). 

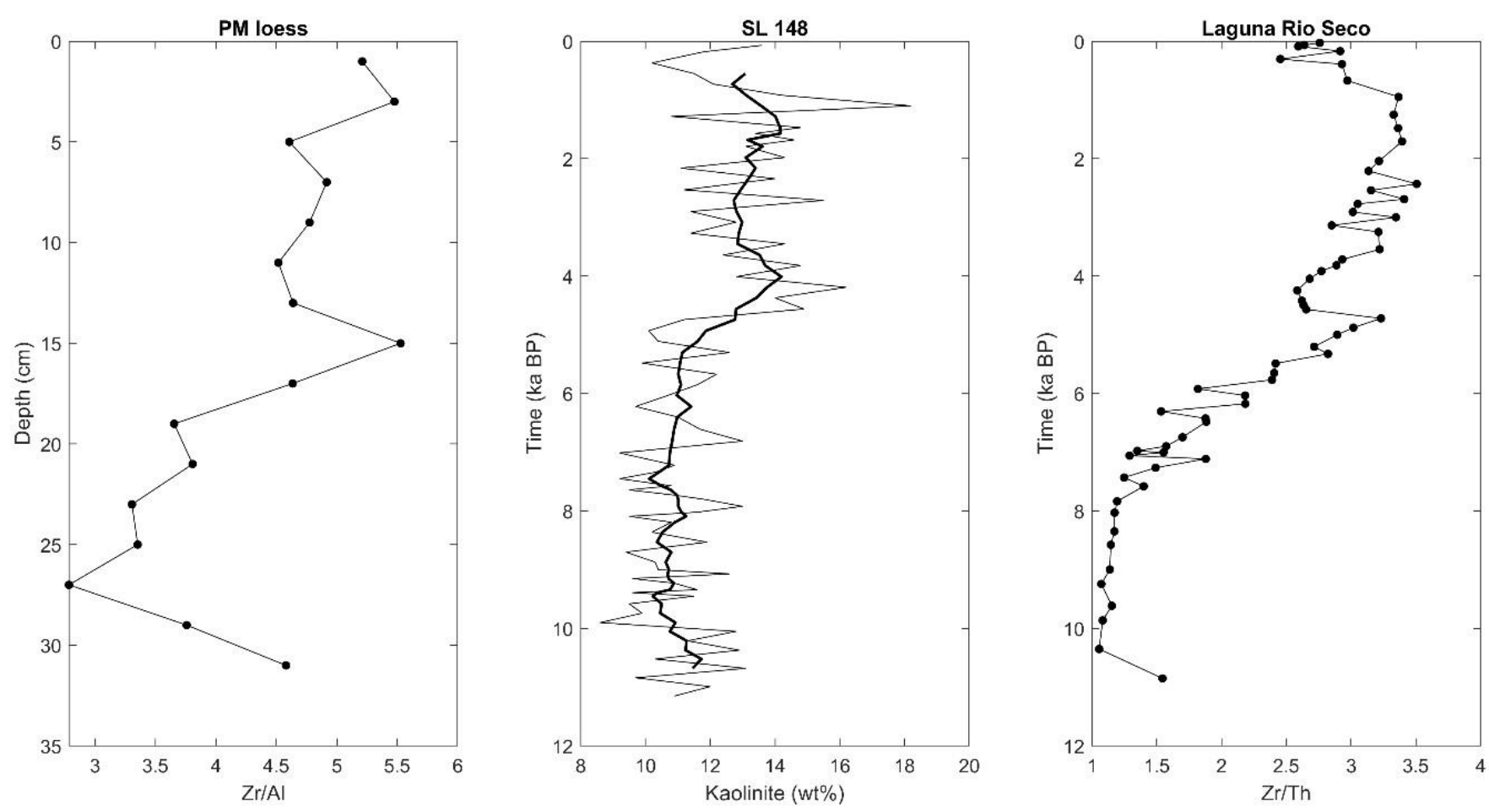

596 Fig. 10. Establishment of relative chronology from comparison with respective proxies of Sahara dust aeolian transport from eastern and western Mediterranean, during the Holocene. $\mathrm{Zr} / \mathrm{Al}$ ratio of PM loess, kaolinite wt\% concentrations of marine core SL 148 (Ehrmann et al., 2007), with thick black line representing the 7-point running mean and $\mathrm{Zr} / \mathrm{Th}$ ratios from laguna Rio Seco in Spanish Pyrenees (Espejo et al., 2014).

600

The formation factors and aeolian dust sources of a Holocene loess sequence deposited in the highest plateau of Greece are assessed for the first time through a multi proxy analysis. The Plateau of Muses (PM) on Mount Olympus, located at $2600 \mathrm{~m}$ is formed by the combined action of karst dissolution and glacial erosion and constitutes a natural trap of locally eroded and aeolian sediments. Collectively, the sedimentological, chemical, mineralogical and magnetic data, along with a relative chronological framework, confirm the hypothesis that deposition of PM loess started $\sim 10 \mathrm{ka} \mathrm{BP}$, following the most recent deglaciation phase on Mount Olympus. Grain size analyses depicted 5 dominant grain size modes in all samples. Calcite rich sandy populations dominated by $\mathrm{Ca}$ and $\mathrm{Sn}$ make up to $95 \%$ of the clast free sediment horizons of glacial and periglacial sediments, collected from the adjacent glacial cirques, 
contrasting the aeolian quartz rich (60\%) silts and clays that dominate (95\%) PM loess sedimentary and mineralogical composition. Glacially derived coarse carbonate sand constitutes a minor proportion (5\%) of its grain size modal contribution, whereas similar Fe/Ti values among the contrasting depositional environments considered, supplemented by SEM imagery, suggest the release of Fe-Ti oxides from bedrock formations and their subsequent enrichment in PM loess in the form of mixed aggregates.

The most dominant dust source of PM loess is Sahara Desert, as the study area is located within the boundaries of intense Sahara dust fallout zone. Local dust sources include the deglaciated slopes of Mount Olympus and the adjacent Pieria Mountains and Katerini plain dominated by ophiolitic alluvial sediments. The aeolian silt fraction of PM loess, expressed by grain size mode M3, shows small variations in its grain size $(15 \mu \mathrm{m})$ and high correlations with $\mathrm{Zr} / \mathrm{Al}$ and mica wt\%, properties representative of modern Sahara dust grain size, mineralogy and geochemical composition. Reduced concentrations of M3 between 10 and $6 \mathrm{ka} \mathrm{BP}$ are attributed to the reduced deflation of quartz rich silts during the most recent AHP and by the dominance of an Atlantic type of climate with enhanced westerlies. A mid-Holocene swift in the regional climate from Atlantic to Mediterranean type with drier conditions and more frequent periods of Scirocco winds coincided with the termination of AHP and increased deflation of Sahara dust grains from the desiccated areas. This regional climatic shift resulted in prominent increases in the aeolian silt deposition (increase of $\mathrm{M} 3$ concentrations) and $\mathrm{Zr} / \mathrm{Al}$ ratio between 6 and $4.5 \mathrm{ka}$ BP, with a concomitant decrease in the pedogenic modification of the deposited dust and decreasing clay particle formation (decrease of M1 and M2 concentrations). Contrary to the enhancement of Sahara dust transport on Mount Olympus since $6 \mathrm{ka} \mathrm{BP}$, is the decrease of local dust from the Pieria mountaintops and Katerini plain, as shown by the correlation of clay and fine silt with $\mathrm{Cr}$ and Ni. The associated decrease of clay concentration with the heavy elements, can result either from decreases either in summer convection and/or to northern winds outbreaks.

PM loess is decalcified and subjected to secondary syn or post depositional chemical weathering, which include removal of $\mathrm{Ca}$ and $\mathrm{K}$ respectively. The upwards decreasing trends of $\mathrm{Ca} / \mathrm{Sr}$ and $\mathrm{K} / \mathrm{Rb}$ imply that the elemental modification of PM loess has been gradual and independent of the aeolian deposition and 
regional climatic dynamics. The secondary mineralogical modification may be responsible for the high amounts of smectite and kaolinite observed in the clay fraction, through weathering of mica to smectite and plagioclase to kaolinite, but further conclusions on these processes cannot be achieved through the analyses presented here. In addition, during deposition of the upper PM loess layer (6- 0 ka BP), wetter than present summer conditions likely resulted in waterlogging and subsequent dissolution of Fe from the Fe-Ti oxides (deferrification) and to pedogenic depletion of the magnetic signal.

Overall, the mechanisms responsible for the formation of PM loess are complex and involve several convoluting processes, such as mechanical weathering of the glacial carbonate debris, chemical dissolution of the weathered products, syn and post depositional alteration and formation of aggregates, pedogenetic modification and aeolian dust deposition from local and regional sources. In the absence of continuous reconstructions from Mediterranean alpine settings, future analyses of alpine loess deposits in the sub $\mathrm{cm}$ scale can provide a powerful tool to study the local weathering dynamics and regional atmospheric circulation patterns, focusing on periods of Sahara dust events and enhanced Sirocco winds throughout the Holocene.

\section{REFERENCES}

Aarons, S.M., Aciego, S.M., Gleason, J.D., 2013. Variable Hf-Sr-Nd radiogenic isotopic composition in a Saharan dust storm over the Atlantic: implications for dust flux to oceans, ice sheet and the terrestrial biosphere. Chem. Geol. 349-350, 18-26.

Allard, J.L., Hughes, P.D., Woodward, J.C., Fink, D., Simon, K., Wilcken, K., M., 2020. Late Pleistocene glaciers in Greece: A new ${ }^{36} \mathrm{Cl}$ chronology. Quat Sci Rev. 245, 106528, (https://doi.org/10.1016/j.quascirev.2020.106528). 
670

671

672

673

674

675

676

677

678

679

680

681

682

683

684

685

686

687

688

689

690

Amit, R., Enzel, Y., and Crouvi, O., 2020, Quaternary influx of proximal coarse-grained dust altered circum-Mediterranean soil productivity and impacted early human culture: Geology, 49 (1), 61 - 65, https://doi.org/10.1130/G47708.1

Anderson S. P., Drever J. I., Frost C. D., Holden P., 2000. Chemical weathering in the foreland of a retreating glacier. Geochim. Cosmochim. Acta 64, 1173-1189.

Anderson S. P., 2005. Glaciers show direct linkage between erosion rate and chemical weathering fluxes. Geomorphology 67, 147- 157.

Bartzokas, A., Lolis, C.J., Metaxas, C.A., 2003. The 850hPa relative vorticity centers of action for winter precipitation in the Greek area. Int. J. Climatol. 23, $813-828$.

Bokhorst, M.P., Beets, C.J., Markovi'c, S.B., Gerasimenko, N.P., Matviishina, Z.N., Frechen, M., 2009. Pedo-chemical climate proxies in late Pleistocene Serbian-Ukranian loess sequences. Quat. Int. 198, 113-123. https://doi.org/ 10.1016/j.quaint.2008.09.003.

Bosq, M., Kreutzer, S., Bertran, P., Degeai, J.-P., Dugas, P., Kadereit, A., Lanos, P., Moine, O., Pfaffner, N., Queffelec, A., Sauer, D., 2020. Chronostratigraphy of two Late Pleistocene loess-palaeosol sequences in the Rhône Valley (southeast France). Quat. Sci. Rev. 245, 106473. doi:10.1016/j.quascirev.2020.106473.

Brooks N, Chiapello I, Lernia SD, Drake N, Legrand M, Moulin C, et al., 2005. The climateenvironment society nexus in the Sahara from prehistoric times to the present day. J North Afr. Stud., 10, 253-92. 
694

695

696

697

698

699

700

701

702

703

704

705

706

707

708

709

710

711

712

713

714

715

716

717

Buggle, B., Glaser, B., Hambach, U., Gerasimenko, N., Marković, S., 2011. An evaluation of geochemical weathering indices in loess-paleosol studies. Quat. Int. 240, 12-21.

https://doi.org/10.1016/j.quaint.2010.07.019.

Buggle, B., Glaser, B., Zöller, L., Hambach, U., Marković, S., Glaser, I., Gerasimenko, N., 2008. Geochemical characterization and origin of Southeastern and Eastern European loesses (Serbia, Romania, Ukraine). Quat. Sci. Rev. 27, 1058-1075. https://doi.org/10.1016/j.quascirev.2008.01.018.

Dearing, J., Hay, K., Baban, S., Huddleston, A., Wellington, E., Loveland, P., 1996. Magnetic susceptibility of soil: an evaluation of conflicting theories using a national data set, Geophys. J. Int., to the retrieval of past global changes-some problems. Phys. Earth 127, 728-734.

Chen, Q., Liu, X., Heller, F. et al., 2012. Susceptibility variations of multiple origins of loess from the Ily Basin (NW China). Chin. Sci. Bull. 57, 1844-1855. https://doi.org/10.1007/s11434-012-5131-1

Croudace, I.W., Rindby, A., Rothwell, R.G., 2006. ITRAX: description and evaluation of a new multifunction X-ray core scanner. Geological Society. Special publications, London.

Dobiński, W., 2005. Permafrost of the Carpathian and Balkan Mountains, Eastern and Southeastern Europe. Permafr. Periglac. Process. 16, 395-398.

Drewnik, M., Skiba, M., Szymański, W., Żyla, M., 2014. Mineral composition vs. soil forming processes in loess soils - A case study from Kraków (Southern Poland), Catena, 119, 166 - 173. http://dx.doi.org/10.1016/j.catena.2014.02.012.

Durn, G. 2003. Terra rossa in the Mediterranean region: parent materials, composition and origin. Geol. Croat. 56, 83-100. 
719 Egli, M., Mirabella, A., Fitze, P., 2003. Formation rates of smectites derived from two Holocene chronosequences in the Swiss Alps. Geoderma 117, 81-98.

721

722

Egli, M., Sartori, G., Mirabella, A., 2010. The effects of exposure and climate on the weathering of late Pleistocene and Holocene Alpine soils. Geomorphology 114, 466-482.

Egli, M., Dahms, D., Norton, K., 2014. Soil formation rates on silicate parent material in alpine environments: Different approaches-different results? Geoderma, 213, 320 - 333.

Ehrmann, W., Schmiedl, G., Hamann, Y., Kuhnt, T., Hemleben, C., Siebel, W., 2007. Clay minerals in late glacial and Holocene sediments of the northern and southern Aegean Sea. Palaeogeogr. Palaeoclimatol. Palaeoecol. 249, 36-57.

Gallego-Torres, D., Martinez-Ruiz, F., Paytan, A., Jiménez-Espejo, F.J., Ortega- Huertas, M., 2007. Pliocene-Holocene evolution of depositional conditions in the eastern Mediterranean: role of anoxia vs. productivity at time of sapropel deposition. Palaeogeogr. Palaeoclimatol. Palaeoecol. 246,424 - 439.

Gild, C., Geitner, C., Sanders, D., 2018. Discovery of a landscape-wide drape of late-glacial aeolian silt in the western Northern Calcareous Alps (Austria): First results and implications. Geomorph. 301, 3952, https://doi.org/10.1016/j.geomorph.2017.10.025.

Goudie, A.S., Middleton, N.J., 2001. Saharan dust storms: nature and consequences. Earth-Sci. Rev. 56, $179-204$.

Hamann Y, Ehrmann W, Schmiedl G, Krueger S, Stuut J-B, Kuhnt T. Sedimentation processes in the Eastern Mediterranean Sea during the Late Glacial and Holocene revealed by end-member modelling of the terrigenous fraction in marine sediments. Mar. Geol. 2008; 248, 97 - 114. 
747 Heller, F., Evans, M.E., 1995. Loess magnetism. Rev. Geophys. 33, $211-240$.

Hošek. J., Hambach, U., Lisá, L., Grygar T.M., Horácek, I., Meszner, S., Knésl, I., 2015. An integrated rock-magnetic and geochemical approach to loess/paleosol sequences from Bohemia and Moravia

751

752

753

754

755

756

757

758

759

760

761

762

763

764

765

766

767

768

769

770

771

772

(Czech Republic): Implications for the Upper Pleistocene paleoenvironment in central Europe.

Palaeogeogr. Palaeoclimatol. Palaeoecol. 418: 344-358 https://doi.org/10.1016/j.palaeo.2014.11.024.

Hughes, P.D., Woodward, J.C., 2016. Quaternary glaciation in the Mediterranean Mountains. A new synthesis. In: Hughes PD, Woodward JC (eds) Quaternary Glaciation in the Mediterranean Mountains. Geol Soc London Spec Publ 433, 1-23.

Hurrell, J.W., Kushnir, Y., Ottersen, G., Visbeck, M. 2016. An overview of the North Atlantic Oscillation. In: Hurrell, J. W., Kushnir, Y., Ottersen, G., Visbeck, M. (eds) The North Atlantic Oscillation: climatic significance and environmental impact. AGU Geophys Mon 134, 1-35.

Jiménez-Espejo, F. J., García-Alix, A., Jiménez-Moreno, G., Rodrigo-Gámiz, M., Anderson, R. S.,

Rodríguez-Tovar, F. J., Martínez-Ruiz, F., Giralt, S., Delgado Huertas, A., Pardo-Igúzquiza, E., 2014. Saharan aeolian input and effective humidity variations over western Europe during the Holocene from a high altitude record, Chem. Geol., 374-375, 1-12. https://doi.org/10.1016/j.chemgeo.2014.03.001.

Kabata-Pendias, A., Pendias, H., 2001. Trace Elements in Soils and Plants. 3rd Edition, CRC Press, Boca Raton.

Kantiranis N., Sikalidis K., Godelitsas A., Squires C., Papastergios G., Filippidis A., 2011. Extraframework cation release from heulandite-type rich tuffs on exchange with NH4+. J. of Env. Man., 92(6), $1569-1576$. 
774 Költringer, C., Stevens, T., Bradák, B., Almqvist, B., Kurbanov, R., Snowball, I., \& Yarovaya, S., 2021.

775 Enviromagnetic study of Late Quaternary environmental evolution in Lower Volga loess sequences, 776 Russia. Quat. Res., 103, 49-73. doi:10.1017/qua.2020.73

Krahtopoulou A, Veropoulidou R, 2017. Late Pleistocene-Holocene shoreline reconstruction and human

779

780

781 exploitation of molluscan resources in northern Pieria, Macedonia, Greece. J. Archaeol. Sci. Rep. 15, $423-436$.

Küfmann, C., 2008. Are cambisols in alpine karst Autochthonous or eolian in origin? Arct. Antarct. Alp. Res. 40, 506-518.

Kuhlemann, J., Rohling, E., Krumrei, I., Kubik, P., Ivy-Ochs, S., Kucera, M., 2008. Regional synthesis of Mediterranean atmospheric circulation during the last glacial maximum. Science 321 (5894), 1338 1340.

Lawrence, C.R., Reynolds, R.L., Ketterer, M.E., Neff, J.C., 2013. Aeolian controls of soil geochemistry and weathering fluxes in high-elevation ecosystems of the Rocky Mountains, Colorado. Geochim. Cosmochim. Acta 107, 27-46.

F. Lehmkuhl, J.J. Nett, S. Pötter, P. Schulte, T. Sprafke, Z. Jary, P. Antoine, L. Wacha, D. Wolf, A. Zerboni, J. Hošek, S.B. Marković, I. Obreht, P. Sümegi, D. Veres, C. Zeeden, B. Boemke, V. Schaubert, J. Viehweger, U. Hambach, 2021. Loess landscapes of Europe - Mapping, geomorphology, and zonal differentiation, Earth Sci. Rev., 215, 103496, https://doi.org/10.1016/j.earscirev.2020.103496. 
797 Lutterotti L., Bortolotti M., Ischia G., Lonardelli I., Wenk H.R., 2007. Rietvelt texture analysis from 798 diffraction images. Zeitschr. für Krist., Suppl. 26, 125-130.

799 Maher, B. \& Thompson, R., 1992. Paleoclimatic significance of the Thompson, R. \& Maher, B.A., 1995.

800 Age models, sediment fluxes and mineral magnetic record of the Chinese loess and paleosols, Quat.

801 Res., 37, 155-170.

802 Maher, B.A., 2011. The magnetic properties of Quaternary aeolian dusts and sediments, and their 803 palaeoclimatic significance. Aeol. Res. 3, 87-144.

804

Marino, G, Rohling, E.J., Sangiorgi, F. et al. (2009) Early and middle Holocene in the Aegean Sea:

806

Interplay between high and low latitude climate variability. Quat. Sci. Rev. 28, 3246-3262.

807

808

809

Mattson, J.O., Niéhlen, T., 1996. The transport of Saharan dust to southern Europe: a scenario. J. Arid Env.

810 $32,111-119$.

811

812 Merino, E., and Banerjee, A. 2008. Terra rossa genesis, implications for karst, and eolian dust: a 813 geodynamic thread. J. Geol. 116, $62-75$.

814

815 Moreno, T., Querol, X., Castillo, S., Alastuey, A., Cuevas, E., Herrmann, L., Mounkaila, M., Elvira, J., 816 Gibbons, W., 2006. Geochemical variations in aeolianmineral particles from the Sahara-Sahel Dust Corridor. Chemosphere 65, 261-270. 
819 Muhs D. R., Bush C. A., Stewart K. C., Rowland T. R., Crittenden R. C.,1990. Geochemical evidence 820 of Saharan dust parent material for soils developed on quaternary limestones of Caribbean and Western 821 Atlantic Islands. Quaternary Res. 33, 157-177.

822

Muhs, D.R., Bettis, E.A., Been, J., McGeehin, J.P., 2001. Impact of climate and parent material on chemical weathering in loess-derived soils of the Mississippi river valley. Soil Sci. Soc. Am. J., 65, $1761-1777$.

826

827

828

829

830

831

832

833

834

835

836

837

838

839

840 Nesbitt, H.W., Markovics, G., Price, R.C., 1980. Chemical processes affecting alkalis and alkaline earths

841 during continental weathering. Geochim. Cosmochim. Act. 44, 1659-1666.

842 https://doi.org/10.1016/0016-7037(80)90218-5.

Muhs, D. R., Budahn J. R., Prospero, J. M., Carey, S. N., 2007. Geochemical evidence for African dust inputs to soils of western Atlantic islands: Barbados, the Bahamas, and Florida. J. Geophys. Res. Atmos. 112, F02009.

Muhs, D.R., Benedict, J.B., 2006. Eolian additions to late Quaternary alpine soils, Indian Peaks Wilderness Area, Colorado Front Range. Arct. Ant. Alp. Res. 38, 120-130.

Nance, R.D., 2010. Neogene-recent extension on the eastern flank of Mount Olympus, Greece.

Tectonophys. 488, $282-292$.

Nastos, P.T., 2012. Meteorological patterns associated with intense Saharan dust outbreaks over Greece in winter. Adv. Meteor. . https://doi.org/10.1155/2012/828301 
Niehlen, T., Mattsson, J., Rappi, A., Gagaoudaki, Ch., Kornaros, G., Papageorgiou, J., 1995. Monitoring of Saharan dust fall out on Crete and its contribution to soil formation. Tellus, 47B, 365-374.

Oliva, M., Žebre, M., Guglielmin, M., Hughes, P.D., Çiner, A., Vieira, G., Bodin, X., Andrés, N., Colucci, R.R., García-Hernández, C., Mora, C., Nofre, J., Palacios, D., Pérez-Alberti, A., Ribolini, A., Ruiz-Fernández, J., Sarıkaya, M.A., Serrano, E., Urdea, P., Valcárcel, M., Woodward, J.C., Yı1dırım, C., 2018. Permafrost conditions in the Mediterranean region since the Last Glaciation, Earth. Sci. Rev., 185, 397-436. https://doi.org/10.1016/j.earscirev.2018.06.018. Persoiu, A., Onac, B. P., Wynn, J. G., Blaauw, M., Ionita, M., and Hansson, M.: Holocene winter climate variability in Central and Eastern Europe, Sci. Rep., 7, 1196.

https://doi.org/10.1038/s41598017-01397-w

Peyron, O., Combourieu-Nebout, N., Brayshaw, D., Goring, S., Andrieu-Ponel, V., Desprat, S., Fletcher, W., Gambin, B., Ioakim, C., Joannin, S., Kotthoff, U., Kouli, K., Montade, V., Pross, J., Sadori, L., and Magny, M.: Precipitation changes in the Mediterranean basin during the Holocene from terrestrial and marine pollen records: a model-data comparison, Clim. Past, 13, 249-265, https://doi.org/10.5194/cp-13-249-2017, 2017.

Profe, J., Zolitschka, B., Schirmer, W., Frechen, M., Ohlendorf, C., 2016. Geochemistry unravels MIS 3/2 paleoenvironmental dynamics at the loess-paleosol sequence Schwalbenberg II, Germany. Palaeogeogr. Palaeoclimatol. Palaeoecol. 459, 537-551. https://doi.org/10.1016/j.palaeo.2016.07.022.

\footnotetext{
Pye, K., 1995. The nature, origin and accumulation of loess. Quat. Sci. Rev. 14, 653-667.
}

Rantitsch, G., Melcher, F., Meisel, Th., Rainer, Th., 2003. Rare earth, major and trace elements in Jurassic manganese shales of the Northern Calcareous Alps: hydrothermal versus hydrogenous origin of stratiform manganese deposits. Miner. Petrol. 77, 109-127. https://doi.org/10.1007/s00710-0020197-0 
872 Rellini, I., Trombino, L., Firpo, M., Rossi, P.M., 2009. Extending westward the loess basin between the 873 Alps and the Mediterranean region: micromorphological and mineralogical evidences from the northern 874 scope of the Ligurian Alps, Northern Italy. Geografia Fisica Dinamica Quaternaria 32, 103-116.

875

876

877

878

879

880

881

882

883

884

885

886

887

888

889

890

891

892

893

894

895

896

Reynolds, R. L., J. Belnap, J., Reheis, M.C., Lamothe, P., Mazza, N., Luiszer, F., 2001. Eolian dust in Colorado Plateau soils: Nutrient inputs and recent change in source, Proc. Natl. Acad. Sci. U. S. A., 98, 7123-7127, doi:10.1073/pnas.121094298

Rohling, E.J., Mayewski, P.A., Hayes, A., Abu-Zied, R.H., Casford, J.S.L., 2002a. Holocene atmosphere-ocean interactions: records from Greenland and the Aegean Sea. Clim. Dyn. 18, 587-593.

Rousseau, D.-D., Chauvel, C., Sima, A., Hatté, C., Lagroix, F., Antoine, P., Balkanski, Y., Fuchs, M., Mellett, C., Kageyama, M., Ramstein, G., Lang, A., 2014. European glacial dust deposits: geochemical constraints on atmospheric dust cycle modeling. Geophys. Res. Lett. 41, 7666-7674. https://doi.org/10.1002/2014GL061382.

Scheuvens, D., Schütz, L., Kandler, K., Ebert, M., Weinbruch, S., 2013. Bulk composition of northern African dust and its source sediments - a compilation. Earth Sci. Rev. 116, 170-194. https://doi.org/10.1016/j.earscirev.2012.08.005.

Smith, B.J., Wright, J.S., Whalley, W.B., 2002. Sources of non-glacial, loess-size quartz silt and the origins of "desert loess". Earth Sci. Rev. 59, 1-26.

Smith, G.W., Nance, R.D., Genes, A.N., 2006. Pleistocene glacial history of Mount Olympus, Greece: Neotectonic uplift, equilibrium line elevations, and implications for climatic change. Spec. Papers Geol. Soc. Am. 409, 157-174. 
898 Stuut, J.B., Smalley, I., O’Hara-Dhand, K., 2009. Aeolian dust in Europe: African sources and European

899 deposits. Quat. Int. 198 (1-2), 234-245. https://doi.org/10.1016/j.quaint.2008.10.007

900

901

902

903

904

905

906

907

908

909

910

911

912

913

914

915

Styllas, M.N., Schimmelpfennig, I., Ghilardi, M., Benedetti. L., 2016. Geomorphologic and paleoclimatic evidence of Holocene glaciation on Mount Olympus, Greece. The Holocene 26 (5), 709721.

Styllas, M. N., Schimmelpfennig, I., Benedetti, L., Ghilardi, M., Aumaître, G., Bourlès, D., Keddadouche, K., 2018. Late-glacial and Holocene history of the northeast Mediterranean mountain glaciers - New insights from in situ-produced ${ }^{36} \mathrm{Clbased}$ cosmic ray exposure dating of paleo-glacier deposits on Mount Olympus, Greece, Quat. Sci. Rev., 193, 244-265, $\underline{\text { https://doi.org/10.1016/j.quascirev.2018.06.020,2018 }}$

Styllas, M.N., Kaskaoutis, D.G., 2018. Relationship between winter orographic precipitation with synoptic and large-scale atmospheric circulation: the case of Mount Olympus, Greece. Bull Geol Soc Greece 52, $45-70$.

Thomas, F., Godard, V., Bellier, O., Benedetti, L., Ollivier, V., Rizza, M., Guillou, V., Hollender, F., ASTER Team., 2018. Limited influence of climatic gradients on the denudation of a Mediterranean carbonate landscape. Geomorph. 316, $44-58$.

Újvári, G., Kok, J., Varga, G., \& Kovács, J., 2016. The physics of wind-blown loess: Implications for grain size proxy interpretations in Quaternary paleoclimate studies. Earth Sci. Rev., 154, 247 - 278.

Varga, G., Cserhati, C., Kovacs, J., Szalai, Z., 2016. Saharan dust deposition in the Carpathian Basin and its possible effects on interglacial soil formation. Aeolian Res. 22. 
https://doi.org/10.1016/j.aeolia.2016.05.004.

Voudouris, P., Melfos, V., Spry, P.G., Bonsall, T.A., Tarkian, M., Solomos, Ch., 2008. Carbonatereplacement $\mathrm{Pb}-\mathrm{Zn}-\mathrm{Ag} \pm \mathrm{Au}$ mineralization in the Kamariza area, Lavrion, Greece: Mineralogy and thermochemical conditions of formation. Miner. Petrol. 94, 85-106.

Wu, L., Krijgsman, W., Liu, J., Li, C., Wang, R., Xiao, W., 2020. CFLab: A MATLAB GUI program for decomposing sediment grain size distribution using Weibull functions. Sed. Geol., 398, 105590. https://doi.org/10.1016/j.sedgeo.2020.105590.

Xoplaki, E., Luterbacher, J., Burkard, B., Patrikas, I., Maheras, P., 2000. Connection between the largescale $500 \mathrm{hPa}$ geopotential height fields and precipitation over Greece during wintertime. Clim. Res. 14, 129-146.

Yang, F., Zhang, G.L., Yang, F. \& Yang, R.M. 2016. Pedogenetic interpretations of particle-size distribution curves for an alpine environment. Geoderma, 282, 9-15

Zech, M., Zech, R., Zech, W., Glaser, B., Brodowski, S., Amelung,W., 2008. Characterization and palaeoclimate of a loess-like permafrost palaeosol sequence in NE Siberia. Geoderma 143, 281-295.

Zhou, L.P., Oldfield, F., Wintle, A.G., Robinson, S.G., Wang, J.T., 1990. Partly pedogenic origin of magnetic variations in Chinese loess, Nature, 346, 737-739.

Zielhofer, C., von Suchodoletz, H., Fletcher, W.J., Schneider, B., Dietze, E., Schlegel, M., Schepanski, K., Weninger, B., Mischke, S., Mikdad, A., 2017a. Millennial-scale fluctuations in Saharan dust supply across the decline of the African Humid Period. Quat. Sci. Rev. 171, 119-135. 
959 Zielhofer, C., Fletcher, W. J., Mischke, S., De Batist, M., Campbell, J. F. E., Joannin, S., Tjallingii, R., 960 El Hamouti, N., Junginger, A., Stele, A., Bussmann, J., Schneider, B., Lauer, T., Spitzer, K., Strupler, 961 M., Brachert, T., Mikdad, A., 2017b. Atlantic forcing of Western Mediterranean winter rain minima 962 during the last 12,000 years. Quat. Sci. Rev., 157, 29-51. 